Article

\title{
Fruit Sector Strategic Management: An Exploration of Agro-food Chain Actors' Perception of Market Sustainability of Apple Innovation
}

\author{
Moritz Zanetti ${ }^{1}$, Antonella Samoggia ${ }^{1, *(1)}$ and Jennifer Young ${ }^{2}$ \\ 1 Department of Agricultural and Food Science, University of Bologna, 40126 Bologna BO, Italy; \\ moritz.zanetti@studio.unibo.it \\ 2 Department of Marketing, University of Auckland, Auckland 1010, New Zealand; \\ jenny.young@auckland.ac.nz \\ * Correspondence: antonella.samoggia@unibo.it
}

Received: 29 June 2020; Accepted: 29 July 2020; Published: 13 August 2020

\begin{abstract}
The fresh fruit industry is a highly dynamic sector in the food market. Fresh fruit chain actors have to adapt to the changing market environment in order to face upcoming challenges. The objective of this study is to analyze the market sustainability of red-fleshed apples (RFA) by exploring consumers' and fresh fruit industry experts' and stakeholders' opinions in Italy and New Zealand. The study was carried out in Italy and New Zealand from December 2018 to June 2019 including 778 consumers and 29 expert and stakeholder interviews. Results show a promising market potential of RFA. Innovative attributes and nutritional value of RFA are the most important factors that push consumers' interest and willingness to buy RFA. New Zealand consumers and women show a higher appreciation of RFA. The nutritional value of the fruit can be a strategic marketing management attribute especially for health-conscious consumers. However, experts think the market for RFA will develop slowly, and will remain a niche product. Some stakeholders are skeptical about consumer RFA appreciation, and fear that RFA are too radical a novelty on the market. The RFA may be perceived as not natural. There is the need to coordinate food chain stakeholders' management practices on RFA. This allows to mitigate risks, set food standards acceptable for all chain stakeholders, and make sustainable economic investment on innovation.
\end{abstract}

Keywords: apple industry; innovation; novel food; red-fleshed apple (RFA); consumer perception; food neophobia; value chain; food chain sustainability

\section{Introduction}

The fruit industry is a highly dynamic and rapidly growing sector on the food market. There is increasing consumers' interest in food with good nutritional value and high safety standards $[1,2]$. Governmental agencies promote the intake of fruit and vegetables to increase human health as suggested by WHO [3]. Consumers perceive fruit as a snack [4], thus fruit products are competing with convenient and less healthy snack products such as chocolate bars, peanuts, crisps, etc. Fruit sector strategic management actions should be taken to guide consumers to sustainable food choices [5].

The perishability of fresh fruit, new production technologies, an increase in product availability, facilitated entrance of low cost and high quality suppliers, the globalization in trade, the increasing power of retail chains, and changes in consumer behavior enhance the competitiveness on the fruit market [1,6]. The fruit industry is therefore facing multiple challenges which call for a consumer-oriented approach to increase the sustainability of the whole chain [2,7]. An important step is to create a long-term environmentally, financially and socially sustainable environment for product innovation 
and differentiation [8]. A consumer-oriented supply chain approach in the fruit industry means promoting new product development, by introducing new cultivars and fruits with distinctive and novel appearance and taste [1,9], and by delivering high quality products with a wide range of produce assortment based on the understanding of consumers' appreciation [10,11]. These interventions should increase the economic sustainability of the value chain, and have an impact on consumers' healthy food choice $[8,12]$.

\subsection{Trends in the Apple Industry}

Apples are one of the main products on the fruit market and are important in consumers' diet. The apple industry is experiencing major challenges due to the increasingly globalized supply chain and the evolution of consumer behavior and fruit preferences. World apple sales have increased in the last ten years with the emergence of new producer countries and the expansion of traditional producers [13]. Apples are produced in the northern as well as the southern hemisphere and are highly exported [13]. New technologies in storage and handling of apple fruit ensure the apple supply for the whole year and around the globe. This can easily lead to an oversupply on the market $[14,15]$. Furthermore, the all-year availability of other fruits increases the pressure on the apple industry. These factors lead to an increase in competition and some authors argue that the apple industry is in a state of hyper competition [15-17] mainly based on price-quality positioning which affects the industry's economic stability. World main apple producers are constantly looking for new markets around the globe to ensure long-term consumers [18,19]. The Asian market, including countries such as China, Taiwan, Vietnam, Thailand and India, is becoming a promising apple export destination for European, American and Australasian apple producers. However, these markets set high quality standards and require constant product innovation [18,20-24].

Apple fruit is perceived by consumers as a commodity product with a positive health impact and is purchased on a habitual basis [25]. Compared to other fruits, there is a good knowledge amongst consumers on apple varieties in the supermarket. The main commercial varieties are recognized by appearance, taste and texture [26]. This consumer awareness pushed the industry to introduce and promote new apple varieties that are more appealing to consumers. A recent trend aims at introducing new apple varieties with brands and trademarks to create consumer awareness and trust [27-29]. These new varieties are selected by adopting a consumer-oriented approach based on consumers' appreciation of the novel and unique apple characteristics. The new varieties are managed with exclusive agro-food standards, and planting and trading rights to guarantee profit for the whole supply chain, and to gain a competitive advantage in the market [14,26]. The apple club varieties' production and commercialization process is implemented with strict coordination management. This allows to guarantee high product quality, regulate market supply, and develop targeted marketing strategies. Club varieties are therefore able to achieve higher market prices with higher profits for chain actors [28,30-34].

Consumers demand consistent fruit quality and seek for varieties with novel taste and appearance and enhanced health properties. The apple industry responded with developing numerous apple varieties with new brands which are ready to enter the market. With this high number of new potential apple varieties, stakeholders are under pressure to select those varieties with the highest market potential based on their uniqueness and consumer preferences. Red-fleshed apples (RFA) are the latest innovation in apple variety development, and attract the attention of industry stakeholders [35-43]. Due to their unique red colored fruit pulp, RFA have a high degree of novelty and bring innovation to the industry [41]. Introducing highly rewarding apple varieties appreciated by consumers can increase the sustainability of the industry's supply chain, and positively impact consumers' food choices $[6,44]$.

\subsection{Consumer Trends and Fruit Perception}

Consumers' food choice is determined by decisions based on conscious, habitual and subconscious considerations [45]. Consumers' perception of a food product is the result of a combination of different 
information regarding the physical properties of the product (appearance, taste), external product information (price, brand, variety, origin), and the retailing environment selling the product (store, vendor, market). With high product standards, consumers are becoming increasingly selective and can choose among various product attributes [2,46]. In today's dynamic horticultural market, the understanding of consumer behavior and values is crucial to increase the profitability of the sector, drive innovation, and guide consumers towards sustainable food choices [6]. Rapid changes in lifestyle, globalization and the availability of information make the modern consumers aware of their purchasing capabilities, and increase product expectation [47].

Convenience is a product attribute that consumers increasingly seek due to the lack of time for food preparation. This is an important factor for the fruit sector as fruit can be presented as a convenient snack eaten out of home [48]. The fresh-cut fruit sector is becoming increasingly popular among consumers and the industry is responding to this trend with constant product innovation $[2,49]$. New fruit mixtures and color combinations with innovative packaging solutions may promote fresh-cut fruit products and increase the nutritional value and health perception [50].

The consumer trend towards a healthy lifestyle in relation to healthy eating is well known and influences food choices. Medical research studies confirmed that eating a moderate amount of fruit can reduce the risk of obesity, several types of cancer, and coronary heart diseases [51]. Past research findings support that fruit is perceived as healthy and an important part of consumer dietary habits. Consumers are increasingly aware about the health benefits of fruit consumption and have also knowledge about phytonutrients (antioxidants, vitamins, fiber) and their impact on health [52]. Food health perception and nutritional awareness depend on sociodemographic and lifestyle factors. Research shows that nationality, age, gender, income level, household composition and the presence of children can impact the health perception of food [2,53-58]. Consumers' actual fruit consumption frequency is still limited $[9,12,47]$. Interventions to promote the intake of fruits should contribute to sustainable consumers' food choices. The understanding of consumers' attitudes towards health and their nutritional knowledge is therefore crucial [54,59].

The high competitiveness of the food sector has pushed companies to innovate food products and place them on the market. The high frequency of launched food products creates ambivalence and skepticism among consumers which lead to an increasing market failure rate of $70-80 \%$ [60]. Authors describe this phenomenon as food neophobia, which is defined as the unwillingness or refusal to eat, or the tendency to avoid, new foods [61-63]. Humans are highly habitual and along with other omnivores tend to reject novel foods. Novel food products are perceived as less tasty and slightly more dangerous. Research shows that the tendency to reject novel foods differs between consumer groups. Consumers who are younger, have a higher educational level, and live in urban areas tend to have lower food neophobia and show a higher tendency to try novel foods $[58,64,65]$ Consumers' food neophobia in the fruit sector might be less expressed compared to other foods such as animal products, due to the similarity of new fruits with already existing ones, in taste and appearance [66]. However, a study carried out in New Zealand with novel yellow-fleshed kiwifruit found that the absence of information about the origin, and the way to use and consume the fruit reduced the purchase intention of the new kiwifruit [66]. Another concern amongst consumers regarding novel fruits is the involvement of food technology. Many consumers are concerned about the use of genetic modification (GM) when facing a fruit with an unusual appearance or taste [66].

For fruit, appearance and taste are the most important factors for consumer product choices. These two features are also recognized by retailers to be the most important when enlarging their assortment [4]. It has been shown that the appearance of a fruit, and especially the color, evokes expectations about sensory and functional product properties such as freshness and nutritional value [67]. Consumers mostly have product-specific color-taste associations where, for example, the red color in peppers might evoke spiciness, while in apples, this is more associated to sweetness. This highlights the importance of providing information about the origin of the color and taste of the unfamiliar fruit to avoid negative associations and increase consumers' purchase intention $[54,67]$. 
Furthermore, nutritional information and health perception of novel foods can reduce food neophobia. Research shows that information on the nutritional value and health benefits of novel foods increases purchase intention and willingness to pay $[57,63,68-70]$. Health-conscious consumers are more inclined to try new fruit products with nutritional and health claims [63,71].

For many consumers, apple is a frequently purchased item and competes with other commodity fruits such as citrus on the market. Many consumers are aware about the nutritional value and health benefits of apples. Apples are rich in various phytonutrients which have health benefits. A moderate intake of apple fruit contributes to gastrointestinal and cardiovascular health, improves cholesterol and insulin sensitivity [25]. Even though the health benefit of the fruit is a principal factor for consumer choice of fruit, it may remain a subconscious thought when choosing an apple in the supermarket $[2,72]$. The main drivers for apple consumption remain taste and texture. Appearance, especially fruit skin color, can elicit taste and eating expectation. Studies show that consumers prefer red peeled apples as they expect them to have better taste and flavor [73,74]. Consumers also appreciate variety when choosing fruit products. New apple varieties with new colors and additional health benefits are valuable for increasing food choice. Thus, understanding consumer trends, beliefs and values is crucial when placing new fruit varieties with particularly novel features on the market [63].

\subsection{Red-Fleshed Apples (RFA)}

Apples with red fruit flesh arouse the interest of many marketing organizations aiming to diversify their product range, increase demand, and create new market opportunities $[35,36,41,75,76]$. RFA are clearly different from traditional apple varieties due to their unique red fruit pulp, and are considered by experts as a novel fruit product $[29,35,37-39,46,77]$ (Figure 1). Stakeholders from Italy and New Zealand are therefore interested in placing RFA on the market to increase product differentiation [29,38-40]. There are a few RFA brands already established, however, they are not yet on the market. A small-scale commercialization of the new fruit has started in northern Italy, Germany and Spain [41]. RFA are not yet widely commercialized in Australasia (Australia, New Zealand) [35]. As it is a novelty on the apple market, the RFA is mostly unknown to the consumer [35].

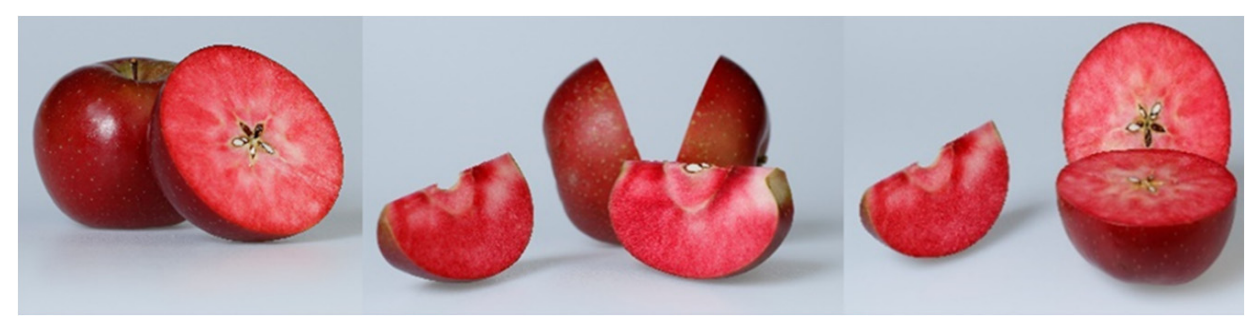

Figure 1. Representation of one commercial brand of RFA (red-fleshed apple) (authors' photograph).

Several research has been carried out on the phytochemical composition of RFA, and their growing and post-harvest management factors [36,78-83]. RFA varieties are of natural origin, and have a high content of phenolic compounds (flavonoids, flavanols, anthocyanins) which accounts for the red color of the fruit flesh, but also a bitter and astringent taste $[78,84,85]$. This increased nutritional value may give RFA a market advantage [82]. Studies point out that a long-term intake of phytonutrients such as phenolic compounds might have a protective effect against cardiovascular and neurodegenerative diseases, diabetes, osteoporosis, and some types of cancers $[75,82,83]$. RFA could therefore be considered as a functional or biofortified food with high nutritional value and therefore, appreciated by health-seeking consumers [36]. RFA could therefore attribute value to the fruit market by positively impacting the profitability of the apple industry chain due to innovation, and by contributing to a healthy and sustainable diet for consumers.

Research shows that there are further challenges on the production and post-harvest management of RFA compared to conventional apple varieties which can lead to higher production costs [84,86-89]. A key aspect is the formation of the internal red color of RFA, as the main quality parameter of 
RFA $[87,89]$. Internal fruit pulp color formation depends on environmental (light and temperature) and orchard management factors such as yield regulation, canopy management, and timing of fruit harvest [87-89]. Moreover, RFA requires different post-harvest and storage treatments as their quality easily degrades with inadequate handling [86]. In order to maintain high fruit quality, avoid fruit disorders and maintain the unique red fruit pulp of RFA, those technical aspects need to be adequately managed. Research shows that RFA achieve high quality when planted in certain pedoclimatic conditions, are harvested at the right ripening stage, and are stored at the right atmosphere [86-89]. Further research is needed to ensure a sustainable market introduction of the fruit.

A sustainable introduction of a novel fruit such as RFA requires research on consumer appreciation. There is little existing research about the market perception of RFA. A study in Italy by Silvestri et al. (2018) [75] reports generally high consumer interest in RFA. However, 36\% rejected RFA with the main concern of genetic modification. Another consumer study on RFA was carried out in 2012 in Italy [35]. This study supports that consumers are skeptical on RFA origin, and limitedly appreciate the new apple variety. Up to a quarter of participants perceived RFA as not real or artificial [35]. These studies provide some information on RFA consumer appreciation. However, more research is needed to better understand RFA perception among consumers, and to identify drivers and barriers of RFA consumer appreciation to facilitate a successful RFA market introduction $[4,67,90]$.

\subsection{Research Aim}

Past research studied consumer preferences of apple fruit in terms of fruit quality (peel color, texture, eating experience), production system and origin. There is little research undertaken on consumers' perception of an apple fruit with novel features such as the red colored fruit pulp of RFA. The aim of this research is to fill this gap in existing literature, and to analyze the market potential of RFA as a novel food product in the fresh fruit market of two horticultural hotspots, Italy and New Zealand. The study aims at providing a better understanding of the market potential of RFA, and of the perceived drivers and barriers of RFA marketing management, by exploring the views of various apple chain actors, that is, producers, distributors, retailers, and consumers. The two main research questions are:

(i) What are consumers' perceptions and appreciation towards the novel RFA fruit? The research aims at providing insights on consumers' views towards RFA market introduction in relation to consumers' innovation and health orientation, RFA perceived nutritional value, naturalness, health perception, and consumers' socio-economic characteristics. In addition, the research explores consumers' purchasing intention, willingness to try and to buy RFA. The study aims at providing a better understanding on possible differences between Italian and New Zealand consumers.

(ii) What are the opinions and interest in RFA market introduction and sustainability among stakeholders and experts in the apple industry? This exploration gathers the views of apple and RFA growers, grower cooperatives, packers, processing industries, fruit retailers, as well as researchers and fruit market experts.

\section{Materials and Methods}

\subsection{Data Gathering}

Data gathering included consumer and stakeholder interviews. Data gathering was carried out from December 2018 to January 2019 in Northern Italy, and from February 2019 to June 2019 in New Zealand.

\subsubsection{Consumer Survey}

The survey questionnaire was designed based on past literature. The survey includes 25 items divided in three main sections. The first section focused on consumer habits for apple consumption, 
factors driving fruit choice, and food neophobia [64,66]. Consumers were asked about their apple consumption frequency (from 0 to 10 times/week) [11,48], and factors affecting their apple fruit choice (taste, convenience, appearance, familiarity with the fruit, nutritional value, habit, origin, variety price, naturalness of the fruit) [11,44]. Food neophobia was assessed through the 9-point Likert Food Neophobia Scale (FNS) designed by Pliner and Hobden (1992) [62]. The FNS includes 10 worded-items about food consumption and eating situations and asks the level of agreement with the proposed items $(1=$ totally disagree to $9=$ totally agree) $[60,62]$.

The second section was based on consumer knowledge, reactions, and opinions about RFA. At the beginning of the section, participants were shown 5 pictures of RFA to make them familiar with the fruit. This section is divided into two subsections. The first subsection asked about familiarity with RFA, their degree of liking RFA, and willingness to try RFA [54,60]. This subsection included questions about consumers' beliefs on the origin (natural, genetically modified, artificial), and nutritional value of RFA $[54,75,91,92]$. Then, consumers were provided with the following information about RFA elaborated from a number of sources:

"RFA have been discovered in wild apple forests in central Asia [81]. The characteristics of those wild RFA have been combined with those from commercial varieties through natural crossing [76]. Therefore, these RFA you see here have the same origin and history as any other apple in the supermarket. The red-fleshed color is due to a higher content of anthocyanins, and antioxidants that you find naturally in different red-colored fruits such as the skin of red apples, in strawberries and red wine $[73,82]$. It has been proven that these antioxidants including anthocyanins have a positive effect on your health by reducing inflammation, reducing the risk of cancer and heart disease, lowering blood pressure, and lowering cholesterol $[25,80,83,93]^{\prime \prime}$.

The second subsection of section two asked consumers to provide feedback on the information received about RFA. This subsection included questions about consumers' interest, reason for their choice, purchase intention and willingness to pay (WTP) for RFA $[46,74,75,92]$. In addition, consumer preference between red- and white-fleshed apples was assessed [72,74,75]. Willingness to pay more for RFA was assessed through a multiple-choice question with a price increase of $25 \%, 50 \%, 75 \%$ and $100 \%$ compared to the average apple price of the specific country [74]. Unless specifically stated, questions were answered using a 5-point Likert scale to express the level of agreement and disagreement $(1=$ totally disagree to $5=$ totally agree $)$.

The third section was aimed at gathering information on consumers' sociodemographic background including gender, age, nationality, level of education, lifestyle, income, and members and/or children in the household. Due to the multicultural environment in New Zealand, ethnicity of the consumer was also asked.

The questionnaire was tested with consumers in both countries to ensure the consumers' understanding of the questions. Unclear items were revised. The survey for New Zealand consumers was adjusted due to different currency and sociodemographic groups.

In both countries, consumers were recruited face-to-face in public places, shopping malls, stores, and coffee shops. Consumers were informed about the purpose of the study, and, if they agreed to participate, were given access to the online questionnaire via link or QR-code, so data would be inputted on the Qualtrics XM software platform. This software allowed to monitor when and where the consumers were filling in the survey, so to control the sources and advancement of the data collection process. In order to reduce bias and randomly distribute the questionnaire, consumers were asked to share the survey with colleagues, friends, and family members using snowballing. Snowball sampling or chain-referral-sampling is a proven sampling strategy used in sociological studies where initial randomly recruited subjects further recruit more waves of respondents which leads to the expansion of the sample [94]. The software platform inhibited double participation in the data upload. The time necessary to fill the questionnaire was around seven minutes. No reward or token was awarded. 


\subsubsection{Interviews with Industry Experts and Stakeholders}

The second part of data gathering included 29 semi-structured face-to-face interviews with experts and stakeholders of the apple and horticultural industry in Northern Italy and New Zealand. Industry experts were identified through online information, newsletters of the horticultural sector and through expert recommendations. The aim was to recruit experts in different positions of the apple and horticultural value chain in both countries in order to obtain a broad understanding of RFA innovation potential in the industry. Fourteen interviews were carried out in Italy, and 15 in New Zealand. Open-ended questions were used in the interviews in a conversational style [95] in order to adapt the interview based on the interviewees attitude, industry awareness and expertise. Interviews lasted around $30 \mathrm{~min}$. Notes were taken during the interviews.

Interview structure with industry stakeholders included four main sections. Specific questions were asked according to the expertise of the interviewed chain member. Therefore, the interview started with questions about general company information and their field of expertise. The first section asked interviewees' opinions on the importance of apple product development and apple variety innovation in their business, and about the features that a new apple fruit product should have to succeed in the market [96]. The second section explored stakeholders' familiarity and knowledge of RFA, and whether they had already heard about, dealt with RFA, and planned to do it in the future. If interviewees were not aware of the new fruit, or did not have a comprehensive background of RFA, they were provided with information about the origin, nutritional value, and current market situation of the fruit and were also shown pictures of the RFA. The third section asked stakeholders' opinions on the agro-food chain drivers and barriers of RFA [14]. In this section, interviewees expressed their opinions over the new fruit's economic sustainability, and why RFA could be an interesting product innovation for the apple market $[9,53]$. Consistent with past research on fruit innovation barriers, stakeholders were asked about their concerns for consumers' possible perception of RFA as genetically modified fruit, and if the higher nutritional value of the fruit would be an important factor for the market management introduction $[4,14,97]$.

The fourth section explored interviewees' economic and technical assessment towards RFA, and their interest in including the new fruit variety in their business. Apple farmers were asked "Would you grow RFA and why?" and retailers, "Would you sell RFA and why?". Interviewees were asked which apple attributes and technical specifications a new RFA variety should have to be accepted by the specific chain actor they belong to $[10,49,75,98]$. Furthermore, interviewed stakeholders were asked about possible markets for the RFA, and which marketing management strategies they would implement for its market introduction $[4,26]$.

\subsection{Data Analysis}

\subsubsection{Consumer Survey}

Data analysis followed three steps. First, the analysis examined consumers' apple consumption habits, apple choice factors, and RFA perception calculating the mean and standard deviation values of questionnaire items. For food neophobia, the consumers' FNS level was calculated by summing the values of each item on the scale per consumer. FNS statements were coded as positive or negative considering consumer's attitude towards FNS. Since items 1, 4, 6, 9 and 10 identify reluctant attitudes, their scores were inputted as a reverse-scale in the calculation of the FNS final score. Then, consumers were divided into quartiles to identify the neophilic, neophobic, and neither of the two, by calculating the FNS cut-out points. Neophilic consumers are in the highest-scoring quarter, and the neophobic consumers are in the lowest-scoring quarter. This elaboration approach is widely applied in the relevant academic literature [97-101].

Second, the study carried out bivariate analyses. Pearson's correlation coefficients were used to assess the relationships between RFA level of appreciation, RFA willingness to try, interest in the RFA nutritional value, RFA willingness to buy, and level of food neophobia. Correlational analyses were 
used to examine the association between consumers' different perceptions of RFA, and the degree to which values of one variable can predict values of the consumers' inclination towards RFA. In addition, the study calculated the Anova of consumers believing RFA is a natural apple and the ones believing RFA is not a natural apple, against RFA level of appreciation, RFA willingness to try, interest in the RFA nutritional value, RFA willingness to buy, and level of food neophobia.

Third, the research developed fourteen hypotheses. These were tested to confirm or to reject them. The research used one-tailed $t$-test, and the Anova to compare the means between two groups in each hypothesis. Since all Anova values confirmed t-test values, the paper includes only these latter ones. The t-test testing was carried out for the whole sample, and for each country, that is, Italian and New Zealand consumers. Hypothesis testing results at country level are in Appendix A. Since some hypotheses involved the distribution of cases among groups, chi-square analysis was carried out. Data elaboration was carried out with the support of SPSS (version 26).

\subsubsection{Expert Interviews}

The interviews with experts were analyzed to identify an apple food industry comprehensive view towards RFA, and to create a consistent framework of the single perspectives through content analysis [102]. The main focus of interview analysis was to highlight drivers and barriers of the RFA market introduction and management including items for the consumer survey. The gathered information was analyzed to find commonalities among the interviewed experts' opinions on the overall sustainability of the market introduction and management of RFA. Therefore, a comprehensive overview of interview responses was made to define a broad picture [103]. In a further step, each interview was analyzed systematically and compared with the outcomes across interviews. Interview information was prioritized based on the research questions to filter the amount of data [104]. Statements for drivers and barriers were grouped based on the chain position and expertise of the interviewee. Data was then broken down into thematic segments based on the relevance of statements in the apple supply chain. Interview statements were categorized according to their meaning for the market potential of RFA (drivers, neutral, barriers), their area of relevance in the apple supply chain (pre-harvest, post-harvest, marketing, distribution and retail) and their significance for the industry (very significant, not significant) $[102,104]$. Further data interpretation and synthesis was used to identify patterns of interview responses, display key results and present descriptive summaries [103].

\subsection{Sample}

\subsubsection{Consumers}

The convenience sample included 778 respondents (Table 1). Most of the interviewees were female (70\%). Nationalities were suitably distributed between Italy and New Zealand. More than half of the participants' sample had a university diploma. The sample population was acceptably balanced between consumers below and above 34 years old in both countries. The income level was concentrated at a medium income level, and more than half of respondents lived without children in their household. 
Table 1. Sociodemographic information of respondents.

\begin{tabular}{cc}
\hline & $\%$ \\
\hline Nationality & \\
Italian & 42.1 \\
New Zealander * & 57.9 \\
Total & 100.0 \\
\hline Gender & \\
Male & 31.2 \\
Female & 68.8 \\
Total & 100.0 \\
\hline Age Group & \\
18-34 & 46.8 \\
$34-50$ & 30.0 \\
$51-64$ & 19.4 \\
$>64$ & 3.8 \\
Total & 100.0
\end{tabular}

\begin{tabular}{|c|c|}
\hline Education & \\
\hline Elementary school or primary school & 0.1 \\
\hline High school & 4.2 \\
\hline Junior high school or intermediate school & 35.5 \\
\hline University diploma/degree (first level, second level, old regulation) & 46.7 \\
\hline Post-university degree diploma (Master, $\mathrm{PhD}$ ) & 13.5 \\
\hline Total & 100.0 \\
\hline \multicolumn{2}{|l|}{ Household members } \\
\hline 1 household member & 12.8 \\
\hline 2 household members & 20.5 \\
\hline 3 household members & 18.8 \\
\hline 4 household members & 27.8 \\
\hline More than 4 household members & 20.1 \\
\hline Total & 100.0 \\
\hline \multicolumn{2}{|l|}{ Children in household } \\
\hline No children in the house & 53.7 \\
\hline 1 child & 12.6 \\
\hline 2 children & 19.7 \\
\hline 3 children & 10.1 \\
\hline More than 3 children & 3.9 \\
\hline Total & 100.0 \\
\hline \multicolumn{2}{|l|}{ Net yearly family income } \\
\hline$<15.000 €$ or $25.000 \mathrm{NZ} \$$ & 12.4 \\
\hline $15.001-28.000 €$ or $25.001-47.000$ NZ\$ & 19.7 \\
\hline $28.001-55.000 €$ or $47.001-90.000$ NZ\$ & 35.5 \\
\hline $55.001-75.000 €$ or $90.001-125.000 \mathrm{NZ} \$$ & 17.2 \\
\hline$>75.000 €$ or $>125.000 \mathrm{NZ} \$$ & 15.2 \\
\hline Total & 100.0 \\
\hline
\end{tabular}

Note: * Among New Zealanders there were 85 respondents from other nationalities, including British, Filipino, German, Australian and Canadian, and living in New Zealand permanently.

\subsubsection{Industry Experts}

Expert interviews were equally distributed between Italy and New Zealand, and were mainly focused in geographical areas with significant apple industry economic, managerial, and agronomic expertise as shown in Table 2. Country experts had various roles in the fresh fruit and apple chain, ranging from production, distribution, processing, retail, to research and consultancy. 
Table 2. List of interviewed experts in Italy and New Zealand with activity, agro-food chain step, and location.

\begin{tabular}{cccc}
\hline Number & Activity in the Horticultural Industry & Agro-Food Chain Step & Location \\
\hline 4 & Italy (14 interviews) & Alto Adige and Veneto \\
3 & Apple growing & Production & Distribution \\
2 & Fruit packing and trading & Alto Adige and Trentino \\
1 & Fruit distribution to retail & Alto Adige \\
1 & Variety management and nursery & Processing & Alto Adige \\
2 & Research in pomology and variety & Research/Consultancy & Trentino \\
1 & innovation & Research/Consultancy & Alto Adige \\
& Food strategy and support & New Zealand (15 interviews) & Bologna \\
\hline 7 & Fruit growing, packing and trading & Production/ Distribution & Auckland and Hastings \\
1 & Retail chain & Retail & Auckland \\
3 & Fruit retail & Retail & Nelson \\
1 & Horticultural consultancy and support & Research/Consultancy & Hastings and Nelson \\
1 & Research in pomology & Research/Consultancy & Hastings \\
& Research in consumer science & Research/Consultancy & Auckland
\end{tabular}

\section{Results}

\subsection{Consumer Survey}

\subsubsection{Consumer Inclination towards RFA}

Respondents showed an average apple consumption of 3-8 times per week (SD = 2.52), and more than half (55\%) consumed apples 1-3 times per week (Table 3). 12\% of consumers did not consume apples frequently. Regarding the factors influencing apple purchase, taste was the most important $(\mathrm{M}=4.3 ; \mathrm{SD}=1.09)$. Other factors, such as familiarity with the fruit $(\mathrm{M}=3.3 ; \mathrm{SD}=1.04)$, appearance $(\mathrm{M}=4.3 ; \mathrm{SD}=1.01)$, nutritional value $(\mathrm{M}=3.11 ; \mathrm{SD}=1.11)$ and good price $(\mathrm{M}=4.3 ; \mathrm{SD}=1.00)$, were rather important.

Table 3. Consumers' apple consumption habits and RFA perception.

\begin{tabular}{|c|c|c|c|c|}
\hline Item & Variable & Mean & SD & Percentage \\
\hline Apple consumption & & 3.8 & 2.52 & \\
\hline \multirow[t]{4}{*}{ Apple choice factors importance } & Taste & 4.3 & 1.09 & \\
\hline & Familiarity & 3.3 & 1.04 & \\
\hline & Nutritional value & 3.1 & 1.11 & \\
\hline & Price & 4.3 & 1 & \\
\hline Food neophobia & & 31.7 & 12.5 & \\
\hline \multirow[t]{4}{*}{ Familiarity with RFA } & & 1.8 & 1.11 & \\
\hline & Low & & & 79.7 \\
\hline & Neutral & & & 7.0 \\
\hline & High & & & 13.3 \\
\hline \multirow[t]{4}{*}{ RFA Liking score } & & 3.8 & 0.86 & \\
\hline & Low & & & 7.8 \\
\hline & Neutral & & & 23.2 \\
\hline & High & & & 69.0 \\
\hline \multirow[t]{4}{*}{ RFA Willingness to try (WTT) } & & 4.4 & 0.77 & \\
\hline & Low & & & 3,0 \\
\hline & Neutral & & & 7.0 \\
\hline & High & & & 90.0 \\
\hline \multirow[t]{4}{*}{ RFA Willingness to buy (WTB) } & & 4.0 & 0.63 & \\
\hline & Low & & & 3.1 \\
\hline & Neutral & & & 8.3 \\
\hline & High & & & 88.6 \\
\hline
\end{tabular}


Table 3. Cont.

\begin{tabular}{ccccc}
\hline Item & Variable & Mean & SD & Percentage \\
\hline Interest in RFA nutritional value & & 4.2 & 0.8 & \\
& Low & & & 3.3 \\
& Neutral & & 12.3 \\
Believe RFA origin to be & High & & 84.4 \\
& Natural & & & 46.6 \\
& GMO & & 38.1 \\
& Artificial & & 2.7 \\
& Other & & 12.6 \\
\hline
\end{tabular}

Note: Mean values are based on a 5-point Likert scale $(1=$ very low; $5=$ very high) except for food neophobia. * Low combines value $1=$ very low and $2=$ low of the 5 -point Likert scale; High combines value $4=$ high and 5 = very high, of the 5-point Likert scale; Neutral includes value 3 answers; ${ }^{* *}$ Question: What is the origin of the red flesh of RFA? Possible answers were: natural, GMO, artificial, other.

Scores on the 9-point bipolar food neophobia scale showed a low average food neophobia of 31.7 $(\mathrm{SD}=12.50)$. Participants were divided in neophilics (score range equal and below 23 , as cut-off for the first quartile), neither neophilic nor neophobic (score between 24 and 40, to capture the second and third quartiles) and neophobics (above 40, to identify the fourth quartile). The level of food neophobia differed in Italy and New Zealand. Italian participants showed a higher food neophobia $(\mathrm{M}=33.6$; $\mathrm{SD}=12.09)$ compared to New Zealand participants $(\mathrm{M}=30.5 ; \mathrm{SD}=12.31) . T$-test analysis confirms the difference $(\mathrm{t}(753)=3.42, p=0.001)$.

Findings underline consumers' perceived novelty and positive inclination towards RFA. $80 \%$ of consumers had never seen the new fruit, and only $12 \%$ had already tasted RFA. Consumers are positively inclined towards RFA. $70 \%$ of respondents liked the new fruit $(\mathrm{M}=3.82, \mathrm{SD}=0.86)$. Around $90 \%$ of participants were willing to try $(\mathrm{M}=4.4, \mathrm{SD}=0.77)$, and willing to buy $(\mathrm{M}=4.0, \mathrm{SD}=0.63)$ the new fruit. Half of respondents were also willing to pay a higher price for the new RFA as compared to common apples. The most important reason to purchase RFA was curiosity $(\mathrm{M}=4.3, \mathrm{SD}=0.62)$, followed by trying something new $(\mathrm{M}=4.2, \mathrm{SD}=0.67)$ and health benefits $(\mathrm{M}=4.0, \mathrm{SD}=0.86) .85 \%$ of consumers were also interested in the nutritional value of the fruit $(\mathrm{M}=4.2, \mathrm{SD}=0.8)$. Participants were indecisive about the origin of RFA. More than half of respondents thought that the color of RFA is not of natural origin, but rather due to genetical modification (38\%), artificial colorants $(3 \%)$, and other $(13 \%)$.

The research analyzed the correlation between key consumers' perceptions of RFA (Table 4). The results support the existence of a statistically significant positive correlation between consumers' RFA appreciation, willingness to try, willingness to buy, and interest in the RFA nutritional value. There is a statistically significant negative correlation between food neophobia level and the other consumers' perceptions of RFA. All the positive coefficients are between 0.249 and 0.457 , whereas the negative correlation is between 0.089 and 0.236 . These findings support that if consumers are interested in the RFA nutritional value, they are willing to buy RFA; if consumers like RFA, they tend to be willing to try RFA. The overall rather positive inclination towards RFA is supported by the food neophobia correlation results. Consumers tend not to appreciate RFA if they are food neophobic. Moreover, results support that consumers that believe that RFA is a natural apple have higher values of RFA appreciation (3.96), RFA willingness to try (4.61), interest in the RFA nutritional value (4.24), and RFA willingness to buy (4.06) (Sign. Anova between 0.000 and 0.051). The level of food neophobia does not vary in relation to the belief of RFA naturalness (Anova Sig. 0.193). 
Table 4. Correlation matrix and Anova between key consumers' opinion on RFA.

\begin{tabular}{|c|c|c|c|c|c|c|}
\hline & & $\begin{array}{c}\text { RFA } \\
\text { Appreciation }\end{array}$ & RFA WTT & $\begin{array}{c}\text { RFA } \\
\text { Nutritional } \\
\text { Value } \\
\text { Interest }\end{array}$ & $\begin{array}{l}\text { RFA } \\
\text { WTB }\end{array}$ & $\begin{array}{c}\text { Food } \\
\text { Neophobia }\end{array}$ \\
\hline \multicolumn{7}{|c|}{ Correlation matrix } \\
\hline RFA & Pearson's $r$ & 1 & 0.453 & 0.249 & 0.383 & -0.236 \\
\hline appreciation & Sig. (2-tailed) & & 0.000 & 0.000 & 0.000 & 0.000 \\
\hline \multirow{2}{*}{ RFA WTT } & Pearson's $r$ & & 1 & 0.271 & 0.356 & -0.182 \\
\hline & Sig. (2-tailed) & & & 0.000 & 0.000 & 0.000 \\
\hline \multirow{2}{*}{$\begin{array}{l}\text { RFA nutritional } \\
\text { value interest }\end{array}$} & Pearson's $r$ & & & 1 & 0.457 & -0.089 \\
\hline & Sig. (2-tailed) & & & & 0.000 & 0.013 \\
\hline \multirow{2}{*}{ RFA WTB } & Pearson's $r$ & & & & 1 & -0.116 \\
\hline & Sig. (2-tailed) & & & & & 0.001 \\
\hline \multirow{2}{*}{ Food neophobia } & Pearson's $r$ & & & & & 1 \\
\hline & Sig. (2-tailed) & & & & & \\
\hline \multicolumn{7}{|c|}{ Anova } \\
\hline \multirow{2}{*}{ RFA is natural } & Mean & 3.96 & 4.61 & 4.24 & 4.06 & 31.15 \\
\hline & Std. Deviation & 0.79 & 0.64 & 0.77 & 0.63 & 12.08 \\
\hline \multirow{2}{*}{$\begin{array}{c}\text { RFA is not } \\
\text { natural }\end{array}$} & Mean & 3.68 & 4.19 & 4.13 & 3.96 & 32.32 \\
\hline & Std. Deviation & 0.90 & 0.82 & 0.82 & 0.63 & 12.73 \\
\hline \multirow{4}{*}{ Total } & Mean & 3.81 & 4.38 & 4.18 & 4.00 & 31.77 \\
\hline & Std. Deviation & 0.86 & 0.77 & 0.80 & 0.63 & 12.44 \\
\hline & $F$ & 20.644 & 62.470 & 3.824 & 4.572 & 1.700 \\
\hline & Sig. & $0.000 * * *$ & $0.000 * * *$ & $0.051^{* *}$ & 0.033 ** & 0.193 \\
\hline
\end{tabular}

Note: ${ }^{* * *}$ sign $<0,001,{ }^{* *}$ sign. $<0,05$. Mean values are based on a 5 -point Likert scale ( $1=$ very low; $5=$ very high).

\subsubsection{Hypothesis Testing}

To investigate consumers' orientation, misconceptions and inclination towards RFA and their potential for market sustainability, 14 hypotheses were defined (Table 5). These hypotheses are based on the past literature analyzed, the insights from the horticultural industry expert interviews, and the authors' expertise in the field.

Table 5. Hypothesis testing with T-test, and mean values.

\begin{tabular}{|c|c|c|c|c|c|c|}
\hline & \multirow{2}{*}{ Variable } & \multirow{2}{*}{ Mean } & \multirow{2}{*}{ St. Dev. } & \multicolumn{2}{|c|}{$T$-Test } & \multirow{2}{*}{ Supported } \\
\hline & & & & $t$-Value & $p$-Value & \\
\hline \multicolumn{7}{|c|}{ Socio-economic characteristics } \\
\hline & & $\begin{array}{l}\text { RFA level of } \\
\text { appreciation } \\
\text { (mean) }\end{array}$ & & & & \\
\hline \multirow[t]{2}{*}{ HP1_Gender } & Male & 3.7 & 0.87 & -2.69 & $0.007^{* * *}$ & Yes \\
\hline & Female & 3.9 & 0.86 & & & \\
\hline \multirow[t]{2}{*}{ HP2_Age (a) } & $<38$ year-old & 3.9 & 0.86 & -3.31 & $0.001 * * *$ & Yes \\
\hline & $=>38$ year-old & 3.7 & 0.85 & & & \\
\hline \multirow[t]{2}{*}{ HP3_Education } & Non-academic & 3.7 & 0.91 & 3.23 & $0.001 * * *$ & Yes \\
\hline & Academic & 3.9 & 0.83 & & & \\
\hline \multirow[t]{2}{*}{ HP4_Country } & NZ & 4.0 & 0.82 & -6.47 & $0.000 * * *$ & Yes \\
\hline & IT & 3.6 & 0.87 & & & \\
\hline \multirow[t]{2}{*}{ HP5_Children } & No children & 3.9 & 0.85 & -1.67 & $0.094 *$ & No \\
\hline & Children & 3.8 & 0.86 & & & \\
\hline \multirow[t]{2}{*}{ HP6_Income (b) } & Low income & 3.9 & 0.84 & -0.10 & 0.918 & No \\
\hline & High income & 3.9 & 0.85 & & & \\
\hline \multicolumn{7}{|c|}{ Consumers' Innovation- and Health-Orientation } \\
\hline & & $\begin{array}{l}\text { RFA level of } \\
\text { appreciation } \\
\text { (mean) }\end{array}$ & & & & \\
\hline
\end{tabular}


Table 5. Cont.

\begin{tabular}{|c|c|c|c|c|c|c|}
\hline & \multirow{2}{*}{ Variable } & \multirow{2}{*}{ Mean } & \multirow{2}{*}{ St. Dev. } & \multicolumn{2}{|c|}{$T$-Test } & \multirow{2}{*}{ Supported } \\
\hline & & & & $t$-Value & $p$-Value & \\
\hline \multirow[t]{2}{*}{$\begin{array}{c}\text { HP7_Apple } \\
\text { choice attributes } \\
\text { (c) }\end{array}$} & $\begin{array}{l}\text { Low importance } \\
\text { of appearance } \\
\text { and nutritional } \\
\text { value }\end{array}$ & 3.8 & 0.86 & -0.09 & 0.927 & No \\
\hline & $\begin{array}{c}\text { High } \\
\text { importance of } \\
\text { appearance and } \\
\text { nutritional value }\end{array}$ & 3.8 & 0.90 & & & \\
\hline \multirow{2}{*}{$\begin{array}{c}\text { HP8_Healthy } \\
\text { diet }\end{array}$} & Not important & 3.8 & 0.79 & 0.36 & 0.720 & No \\
\hline & Important & 3.8 & 0.88 & & & \\
\hline \multirow{3}{*}{$\begin{array}{c}\text { HP9_Food } \\
\text { Neophobia (FN) } \\
\text { (d) }\end{array}$} & & & & & & \\
\hline & Low FN & 4.1 & 0.75 & 5.34 & $0.000 * * *$ & Yes \\
\hline & High FN & 3.7 & 0.88 & & & \\
\hline
\end{tabular}

Consumers' RFA perception

RFA level of appreciation

(mean)

HP10_RFA Belief origin (e)

HP11_Belief in
RFA nutritional
value

HP12_RFA nutritional value interest

HP13_RFA

WTT_WTB (f)

Natural origin
$\begin{gathered}\text { Not natural } \\ \text { origin }\end{gathered}$

Low belief in

RFA nutritional value

High belief in

RFA nutritional value

Low interest in

RFA nutritional value

High interest in

RFA nutritional value

NWTT

RFA_NWTB

RFA

NWTT

RFA_WTB RFA

Low interest in

RFA nutritional value

Nutritional

value interest

High interest in

RFA nutritional value

4.0

3.7

WTT RFA

(mean)

4.2

4.6

WTB RFA

(mean)

3.5

4.1

$\%$

price (mean)
0.79

$-4.54 \quad 0.000^{* * *}$

Yes

0.84

8.04

0.000 ***

Yes

0.64

0.87

11.06

0.000 ***

Yes

WTP RFA higher
39.5

60.5

1.46

0.68

2.66

$0.008 * * *$

Yes

66.59

$0.000^{* * *}$

Yes

1.65

0.74

Note: ${ }^{*}{ }^{* *} ;{ }^{* *}$ Significant at $\mathrm{p}<0.10 ; \mathrm{p}<0.05 ; \mathrm{p}<0.01$; Mean values represent as specified in the table: RFA level of appreciation (How do you like RFA?), willingness to try RFA (WTT), willingness to buy RFA (WTB) and willingness to pay a higher price for RFA on a 5-point Likert scale. The term "Low" groups responses as $1=$ very low, $2=$ low, and $3=$ neutral; and the term "High" groups responses as $4=$ high, and $5=$ very high on a 5 -point Likert scale. (a) The sample average age is 38. (b) $28.000 €$ or $47.000 \mathrm{NZ} \$$ was used as cut-off point. (c) Appearance and nutritional value were the tested attributes. (d) FNS score 23 was used as cut-off point comparing low food neophobia versus medium and high food neophobia. (e) Perceived origin of RFA: Possible answers were Natural versus Other that included genetically modified, artificial, other. (f) Values in percentage represent consumers not WTT (NWTT) and not WTB (NWTB) RFA after receiving information on the characteristics of RFA, and consumers not WTT but WTB RFA after receiving information on the characteristics of RFA. HP13 was tested with Pearson chi ${ }^{2}$ with $\mathrm{df}=1$. 
(i) Socio-Economic characteristics

Hypothesis 1 (HP1). RFA appreciation is higher in female consumers (vs. male).

Hypothesis 2 (HP2). RFA appreciation is higher in younger consumers (vs. older).

Hypothesis 3 (HP3). RFA appreciation is higher in consumers with higher educational level (vs. low educational level).

Hypothesis 4 (HP4). RFA appreciation is higher among New Zealand consumers (vs. Italian consumers).

Hypothesis 5 (HP5). RFA appreciation is higher in consumers with children in their household (vs. no children).

Hypothesis 6 (HP6). RFA appreciation is higher in consumers with higher income level (vs. low income level).

(ii) Consumers' innovation and health orientation

Hypothesis 7 (HP7). RFA appreciation is higher in consumers who attribute high importance to apple appearance and nutritional value (vs. consumers who attribute low importance to apple appearance and nutritional value).

Hypothesis 8 (HP8). RFA appreciation is higher in consumers who attribute higher importance to a healthy diet (vs. consumers who attribute low importance to a healthy diet).

Hypothesis 9 (HP9). RFA appreciation is higher for consumers with lower food neophobia (vs. low food neophobia).

(iii) Consumers' RFA perception

Hypothesis 10 (HP10). RFA appreciation is higher for consumers who believe the red color of the RFA is of natural origin (vs. consumers that believe it is GMO, artificial).

Hypothesis 11 (HP11). Willingness to try RFA is higher in consumers with higher expectations about the RFA nutritional value (vs. low expectations about nutritional value).

Hypothesis 12 (HP12). Willingness to buy RFA is higher in consumers with higher interest in the nutritional value of RFA (vs. low interest in nutritional value).

Hypothesis 13 (HP13). Unwillingness to try RFA turns into willingness to buy, after consumer has received information about RFA origin and nutritional value of the fruit.

Hypothesis 14 (HP14). Willingness to pay for RFA is higher in consumers with higher interest in the nutritional value of the RFA (vs. low interest in nutritional value of RFA).

(HP1) Results support a significant higher appreciation of RFA in females $(\mathrm{M}=3.9, \mathrm{SD}=0.86)$, compared to males $(M=3.7, S D=0.87)$, as confirmed by the $T$-test $(\mathrm{t}(769)=-2.69, p=0.07(\alpha=0.10))$. Thus, HP1 is supported by the results.

(HP2) Younger consumers have a higher appreciation of RFA $(M=3.9, S D=0.86)$ than older consumers $(\mathrm{M}=3.7, \mathrm{SD}=0.84)$. The difference is statistically significant $(\mathrm{t}(737)=-3.54$. $p=0.00$ with $\alpha=0.05)$, therefore HP2 is accepted.

(HP3) Results show that consumers' educational background does affect the perception of the RFA. Consumers with an academic educational level like RFA more $(\mathrm{M}=3.9, \mathrm{SD}=0.83)$ than consumers with lower educational level (i.e., non-academic) $(\mathrm{M}=3.7, \mathrm{SD}=0.91)$. The difference between the two groups is statistically significant $(t(761)=-3.23 . p=0.00$ with $\alpha=0.05)$, therefore HP3 is accepted. 
(HP4) Results show that respondents' nationality impacts on the RFA acceptability. New Zealanders $(M=4.0, S D=0.82)$ show a significantly higher appreciation of RFA than Italians $(\mathrm{M}=3.6, \mathrm{SD}=0.87)$. HP4 can be accepted with $t(753)=-6.74, p=0.00$ and $\alpha=0.05$.

(HP5) Results support that consumers with children in their household $(\mathrm{M}=3.8, \mathrm{SD}=0.86)$ like RFA less than consumers without children in their household $(\mathrm{M}=3.9, \mathrm{SD} 0.85)$. The results are moderately significant $(t(689)=-1.67, p=0.09$ with $\alpha=0.10)$. Findings are the opposite as hypothesized, therefore HP5 was rejected. Consumers with children in their household do not have a higher appreciation of RFA than consumers without children in their household.

(HP6) Results show that high- and low-income consumers showed similar liking scores of RFA with the same mean value $(\mathrm{M}=3.9)$ and no statistical difference $(t(674)=-0.1, p=0.92)$. RFA appreciation is not different between high- and low-income consumers. HP6 is not accepted.

(HP7) Consumers who attribute high $(\mathrm{M}=3.8, \mathrm{SD}=0.90)$ and low $(\mathrm{M}=3.8, \mathrm{SD}=0.86)$ importance to apple appearance and nutritional value equally accept RFA. This is supported by the $t$-test values $(t(767)=-0.09, p=0.93)$. Thus, HP7 was rejected.

(HP8) Results do not support a statistical difference in RFA appreciation between consumers who attribute high $(\mathrm{M}=3.8, \mathrm{SD}=0.88)$ and low $(\mathrm{M}=3.8, \mathrm{SD}=0.79)$ importance to a healthy diet $(t(769)=-0.36, p=0.72)$. HP8 was therefore not supported.

(HP9) Consumers with low food neophobia ( $\mathrm{M}=4.1, \mathrm{SD}=0.75)$ are hypothesized to like RFA more, compared to consumers with low food neophobia $(\mathrm{M}=3.7, \mathrm{SD}=0.88)$. The difference in RFA appreciation between high and low food neophobic consumers is significant $(t(770)=5.34, p=0.00$ with $\alpha=0.05)$. HP9 is confirmed. Consumers with low food neophobia show higher appreciation of RFA than consumers with high food neophobia.

(HP10) Consumers that believe RFA are of natural origin $(\mathrm{M}=4.0, \mathrm{SD}=0.79)$ like RFA more than consumers who believe the fruit is not natural (i.e., genetically modified and artificial) $(\mathrm{M}=3.7$, $\mathrm{SD}=0.90)$. The difference is statistically significant $(t(770)=-4.54, p=0.00$ with $\alpha=0.05)$. Thus, HP10 is supported. Appreciation of the RFA is higher in consumers who believe the fruit is of natural origin vs. consumers who believe the red color of the fruit flesh is artificial or due to genetic modification.

(HP11) Consumers that expected a higher nutritional value of RFA $(\mathrm{M}=4.6, \mathrm{SD}=0.64)$ have a higher willingness to try (WTT) the novel apple, compared to consumers who had low expectations about the fruit's nutritional value $(\mathrm{M}=4.2, \mathrm{SD}=0.87)$. The difference in the willingness to try the fruit between consumers with high versus low expectations about the nutritional value of RFA is statistically significant $(t(772)=8.04, p=0.00$ with $\alpha=0.05)$. HP11 was supported.

(HP12) Consumers with high interest in the nutritional value of RFA $(\mathrm{M}=4.1, \mathrm{SD}=0.52)$ are hypothesized to be more willing to pay for the novel fruit compared to consumers who have low interest in the fruit's nutritional value $(\mathrm{M}=3.5, \mathrm{SD}=0.87)$. The difference was statistically significant $(t(769)=11.06, p=0.00$ with $\alpha=0.05)$. Results support HP12. Thus, results support that consumers with high interest in the nutritional value of RFA are more willing to pay for the novel fruit than consumers who show low interest in the fruit's nutritional value.

(HP13) Consumers unwilling to buy RFA are hypothesized to be willing to buy the novel fruit after they have received information about the origin and nutritional value of the fruit. $60.5 \%$ of consumers who are not willing to try RFA were willing to buy the fruit after they were provided with the information, and $39.5 \%$ still did not want to buy the fruit. The results are statistically significant $\left(c h i^{2}(1)=66.59, p=0.00\right.$ with $\left.\alpha=0.05\right)$. Thus, HP13 is supported. Providing information about origin and nutritional value of the fruit increases willingness to buy in consumers who were not firstly willing to try the fruit.

(HP14) Consumers with high interest in the nutritional value of RFA $(\mathrm{M}=1.65, \mathrm{SD}=0.74)$ are hypothesized to have a higher willingness to pay for the fruit compared to consumers with low interest in the fruit's nutritional value $(\mathrm{M}=1.46, \mathrm{SD}=0.68)$. The difference is statistically significant $(t(762)=2.67, p=0.00$ with $\alpha=0.05)$, and therefore HP14 was supported. Willingness to pay for RFA 
was higher in consumers with high interest in the nutritional value of RFA, compared to consumers with low interest in its nutritional value.

All supported hypotheses (i.e., HP1, HP2, HP3, HP4, HP9, HP10, HP11, HP12, HP13 and HP14) were tested in a cross-country comparison with New Zealand versus Italian consumers (see Appendix A). Results support that women $(\mathrm{M}=4.1, \mathrm{SD}=0.79)$ have significantly higher appreciation of RFA compared to men $(\mathrm{M}=3.8, \mathrm{SD}=0.86)$ only in New Zealand $(t(435)=-2.34, p=0.02$ with $\alpha=0.01)$. Thus, HP1 was confirmed only for New Zealand consumers. With regard to age impact on RFA acceptability (HP2), only Italian consumers showed significant statistical differences in RFA appreciation between young $(\mathrm{M}=3.8, \mathrm{SD}=0.86)$ and older $(\mathrm{M}=3.4, \mathrm{SD}=0.81)$ consumers $(t(315)=-3.72, p=0.00$ with $\alpha=0.05)$. HP2 was confirmed for Italian consumers. In New Zealand, no difference in RFA appreciation between young and older consumers was observed. Moreover, no statistical difference in liking RFA was shown in consumers based on their level of education (academic versus non-academic) and number of children in their household (no children versus one or more children). HP3 and HP4 were therefore rejected at country level. HP9, HP10, HP11, HP12, HP13 and HP14 were supported with statistical significance in both countries and follow the trend of the whole sample. In both countries, consumers with low food neophobia showed higher appreciation towards red-fleshed apples (IT: $\mathrm{M}=3.9, \mathrm{SD}=0.77 ; \mathrm{NZ}: \mathrm{M}=4.2$, $\mathrm{SD}=0.73$ ) than consumers with high food neophobia (IT: $\mathrm{M}=3.5, \mathrm{SD}=0.87 ; \mathrm{NZ}: \mathrm{M}=3.9, \mathrm{SD}=0.73$ ).

\subsection{Industry Perspective on RFA Market Sustainability}

The stakeholders' and experts' interviews are presented focusing on the experts' chain role, and on possible differences between the horticultural industry views in northern Italy and New Zealand. Stakeholders and experts of the apple fruit industry in both countries were knowledgeable about the existence of RFA. Interviewees supported that RFA are an interesting and economically sustainable innovative product for the apple industry with added value for all fruit supply chain stakeholders. Industry stakeholders are interested in including RFA in their product portfolio, as they believe it is an economically sustainable product innovation for the apple industry. Experts were optimistic about the market potential of the fruit.

\subsubsection{Fruit Production and Processing}

Apple producers and processors underlined the importance of finding an apple variety with an optimal product attribute balance to gain a competitive advantage in the apple business market. Exceptional taste, eating experience, and appearance, which differ from existing varieties, were mentioned as the most important attributes for a new apple variety. Interviewees were aware of the existence of RFA, and some stakeholders had already started to introduce and manage RFA in their business, or had already planned it for the next few years. Interviewed experts underlined that red colored fruit pulp is a desired trait for new successful apple varieties on the market. Especially, Italian producers and farmer cooperatives think that RFA can contribute to remain competitive on the European apple market.

Apple producers and processors were positively inclined towards the potentiality of RFA for two main reasons. First, they consider the red flesh color as a positive feature for a new apple variety. RFA can be a new and differentiated fruit product. The distinct color can help open new markets. "The red fruit flesh is a new and distinctive attribute, whose combination of good taste and easy handling of the fruit would guarantee a success on the market", commented one New Zealand fruit producer. Second, apple producers and processors appreciate RFA unique appearance and nutritional value. These characteristics would satisfy the needs of health-conscious consumers. "The new apple does not even have to taste excellent as long as it looks new and has some added nutritional value", stated an Italian producer.

Furthermore, other Italian and New Zealand interviewees claim the new fruit has a high potential for the Asian market. This market is usually open to novelties in the fruit sector. However, some interviewees think that the Asian fruit market appreciates sweet fruit, and may not appreciate the 
acidity of RFA. A minority of experts support that the RFA variety will occupy only a small niche in the apple market, and its demand may increase slowly. Therefore, some stakeholders suggested increasing the production gradually along the years in order to adjust production in reaction to the market evolution.

Interviewees of both countries expressed their interest to include RFA varieties in their business. However, fruit producers and processors raised some concerns on the new apple variety. First, apple producers in Italy and New Zealand were concerned about agronomical and technical aspects of RFA. The main concerns refer to difficulties on the agricultural production (e.g., yield, production cost, and pre-harvest management), and in storage (e.g., storability, homogeneity of production, and post-harvest management). Interviewees support that the RFA variety should have the same growing characteristics as existing apple varieties. If new, it should be "easy to grow, disease-resistant, and have high and stable yields." Interviewees working in the storage, handling and packing of fruit underlined that the RFA variety should have a uniform flesh coloration across the fruit pomes, and maintain it during storage and handling until they reach consumers. Second, producers expect a higher price $/ \mathrm{kg}$ from RFA, as well as higher production costs. Interviewees were concerned that the overall profit of the new variety would only be equal or less than conventional apple varieties. Third, some interviewees believe that the retailers and the consumers may not be ready for such an innovative product. The color of the fruit flesh might be too intense and distinctive compared to the normal apple. This may confuse consumers. Fourth, processors are concerned about the RFA taste. Consumers have a clear idea of the taste of the favorite apple based on the apple skin color. The RFA taste is slightly acidic, not common in red-skinned apples that tend to be sweet. The mismatch between expected taste and fruit color may lead to a negative eating experience.

\subsubsection{Fruit Wholesaling and Retailing}

Wholesalers and retailers had limited knowledge of RFA, especially in New Zealand. Some managers of medium-size fruit retailers had never heard about RFA. Italian interviewees in the fruit retailing sector were knowledgeable about the new fruit, and had tested RFA in some marketing trials. All interviewees have a general positive inclination towards the new fruit, but express some concerns. Italian fruit distributors believe RFA have a high potential, because "retailers tend to demand variety, and always seek for new and innovative products." However, the interviewees identified some challenges. First, the available amount of RFA is not yet able to satisfy retailers' demand. The production must increase to be marketed by retailers, and to achieve a higher number of consumers. Second, there is inadequate information on the RFA apple variety. "Marketing trials have shown that RFA sales need to be accompanied with precise information about origin, taste and nutritional value, in order to convince the consumer", claimed one interviewee in fruit distribution. A simple and easy understandable statement or symbol on the fruit skin or packaging, which suggests the natural origin of the RFA is crucial for the market introduction. Information on the RFA fruit would improve consumers' familiarity with the product, reduce the fear of trying it, and make consumers appreciate its distinctive and unconventional features. Third, RFA might be sold with a high market price. However, an excessive pricing could lead to the market failure. Consistently with producers, distributors and retailers believe that the RFA variety will be a "niche product", occupying a small segment on the apple market. "Conventional consumers will prefer a conventional apple, and it will take time before they try the new apple", commented one interviewee.

Italian and New Zealand distributors and retailers believe RFA have a competitive advantage, thanks to their nutritional value, color, and strategic use in the processing industry. First, RFA have a specific nutritional value for their antioxidant content. This can be appreciated by the consumers, that are increasingly purchasing healthy food. Second, RFA can be used in a number of food products, such as apple juice, cider, dried apple rings, and ready-to-eat fruit salads. Thus, RFA can be an innovative ingredient for the fruit processing industry. Third, the red color can make the product attractive for the consumer, and strengthen the perception of the nutritional value. This last feature was 
particularly appreciated by wholesalers and retailers. However, bigger food retailers are worried about consumer appreciation of the new product, and suggest consistent marketing management and sales monitoring activities. In particular, retailers believe that consumers may perceive RFA as genetically modified. To address this issue, they suggest using a GMO-free labelling, and would appreciate an organic certification. Smaller fruit wholesalers are keen to increase their fruit assortment with RFA, to include processed products formulated with RFA as ingredients, valuing its nutritional content.

\subsubsection{Researchers in the Apple Industry}

This group of interviewees included pomologists, marketing researchers, consumer scientists, and horticultural consultants. They were aware of RFA existence, had good knowledge of their agronomic and market characteristics and were knowledgeable of the different RFA varieties. Some researchers had been involved in testing the new type of apple on the field, in storage, and in the market. Fruit market and consumer researchers consider RFA as an interesting market innovation thanks to the distinctive and novel colored fruit flesh. They underlined the importance of adopting new apple varieties for a sustainable fruit market development. In particular, interviewees believe the new and distinctive variety of RFA may be exploited to build a highly-positioned fruit brand. "RFA varieties have been in a testing phase from an agronomical and marketing point of view for several years already. The new generation of RFA varieties might now be ready to enter the market", claimed a researcher.

Some researchers underlined that new products on the apple shelves can contribute to increasing healthy food consumption. In their view, RFA might be attractive for new consumer segments, especially the younger generation. Interviewees support that RFA have a significant market potential because they fit into the increasing interest in healthy eating, and thus, a higher demand for healthy food. Most of the interviewees believe that consumers will accept RFA. "The modern consumer seeks innovative products and is willing to try them, especially if they are healthy", commented a New Zealand consumer scientist. They highlighted that the market success of other new fruit products, such as the yellow kiwifruit, nashi pears, and different exotic fruits, make the consumer ready for innovation, and increase the willingness to try new products. "RFA are just one of many novelties, why should a consumer be afraid to try them?" a researcher claimed. However, in order to build consumer trust, the product must have good taste and a pleasant eating experience.

In conclusion, RFA can be an interesting apple market innovation with good economic sustainability expectations for the apple industry. Experts believe this new apple variety can bring added value across the entire supply chain. Uniqueness, color, and nutritional content are the key attributes that could lead to a competitive advantage in the fruit market. The downstream chain stakeholders underlined the importance of promoting the health benefits. The nutritional content of RFA may be the attribute to differentiate this apple on fruit market, and follow the rapidly expanding segment of the health-conscious consumers. Researchers, scientists and consultants are the most optimistic about the market success of the RFA, and believe consumers will accept this new fruit. Producers and big retailers expressed significant concerns. Producers perceived challenges due to the agronomic characteristics of RFA, such as shelf-life and storability. Retailers focused their concerns on the consumer appreciation. Italian experts were more familiar and knowledgeable about RFA than New Zealand interviewees. Opinions were consistent across Italian and New Zealand experts.

\section{Discussion}

The present research results provide insights into the strategic marketing management potential and sustainability of the novel RFA, exploring the views of key actors of the RFA agro-food chain, that is, consumers, and fruit industry experts and stakeholders. Findings underline the novelty of RFA. The fruit is not familiar among consumers and only partially among fruit industry experts. This highlights the importance of understanding the market potential and sustainability of the RFA for the definition of effective management decisions. Findings support past research on consumers' 
perception of RFA [75]. Consumers and industry experts are positively inclined towards RFA and its market introduction, which suggests a promising market potential and overall supply chain sustainability. However, the present study findings support the existence of some concerns and misconceptions for the new fruit.

RFA fruit awakens curiosity among consumers, together with a certain level of attraction, but also of skepticism. First, consumers like the RFA red colored fruit flesh, are willing to try the fruit, and are interested in purchasing it. From $70 \%$ to $90 \%$ of participants responded positively to these statements, and half of the participants are willing to pay a higher price for purchasing RFA. These results suggest a consumer inclination to purchase RFA at the first stage of their market introduction.

Second, there is growing interest from consumers and the food industry in food products with high nutritional value and health beneficial properties [52]. An important strategy to increase fruit consumption is the communication of its health benefits [59]. RFA varieties are rich in phenols and have high antioxidative properties [82]. This RFA specific attribute might increase market appreciation, as it contributes to a healthy and sustainable diet. Results support that more than half of consumers expect a high nutritional content from RFA, and only few $(6 \%)$ think the fruit has a low nutritional value. These findings might be explained by consumers' increased nutrition knowledge about what is beneficial for health [54]. Therefore, the red color of the fruit flesh might be associated by consumers with a high content of phytonutrients similar to other red colored fruits such as strawberries, blueberries, grapes, raspberries cherries, etc. Research findings support a high consumer interest in the nutritional value of RFA.

Third, consumers are skeptical regarding the origin of the red colored fruit pulp of RFA. Almost $40 \%$ of consumers think the RFA variety has been genetically modified. This misconception can hamper the market sustainability of the new fruit as the natural integrity of a food product is considered healthy, while artificial or GMO products are perceived as unhealthy [46,105]. Current research findings support that misconceptions about RFA origin may reduce the consumer appreciation.

Fourth, sociodemographic characteristics and food choice factors influence RFA perception. Women have a higher appreciation of RFA compared to men, because they are more interested in the nutritional value of the fruit. These findings are aligned with past research on food perception and eating behavior across gender where women are shown to be more health-conscious and more open to food innovation compared to men [106-108]. Findings support that younger consumers, and consumers with higher education level have a greater appreciation of RFA. These findings confirm past research. Younger consumers are more inclined towards food innovation [48,60], and consumers with higher education have greater knowledge about food, as well as being more careful about their food choices [101]. Their inclination towards RFA might be explained by the nutritional value this consumer segment seeks. RFA is a fruit with a novel feature and can therefore be perceived as a novelty by consumers [4] Novel food products have a high risk of being rejected by consumers with high food neophobia $[33,62]$. The current study confirms previously mentioned research where consumers with higher food neophobia express lower appreciation of novel RFA.

Fifth, country of origin and culture influence consumers' appreciation of new foods [12]. New Zealand consumers have a lower degree of food neophobia compared to Italians. This leads to New Zealand consumers' greater appreciation towards RFA with higher rates of liking, interest in the nutritional value, and purchase intention, compared to Italians. New Zealand consumers are exposed to a high diversity of cultures, different lifestyles, and habits of people. These aspects make them open to novelties, which may turn into a lower level of food neophobia. Italians tend to be more conservative, with higher levels of food neophobia which leads to a lower appreciation of RFA.

Based on the analyzed research hypotheses and feedback from industry experts, two main drivers of RFA were identified. First, the novelty of the fruit awakens consumer curiosity and willingness to try RFA, especially for innovation-seeking consumers. Fruit industry experts' feedback and the consumer survey highlight the significant market appreciation of RFA. The current study findings are relevant for the apple market sustainability of other new markets, traditionally open to innovation. 
The Asian market, strategic for the European and New Zealand apple industry and open to food innovations from foreign countries, may be interested in RFA. Second, the nutritional content of RFA fits with the trend of healthy eating and might increase the fruit's market potential. Industry experts from different steps of the value chain underline the strategic advantage of RFA due to its nutritional value. This highlights RFA market potential not only as fresh fruit, but also as an ingredient for the fruit-processing industry by enhancing the nutritional value of products.

The present study highlights the barriers for RFA market introduction and supply chain sustainability. First, the main concern of RFA market sustainability, as mentioned by industry experts and confirmed by the consumer survey, is the consumer rejection of the novel fruit variety due to the unusual color of the fruit pulp which deviates from the consumers' traditional image of apples. This causes neophobic reactions. Concerns from experts were consistent throughout the whole chain from growers, processors to retailers. Second, there is a notable risk of misbelief about the RFA origin. This can be easily associated with genetic modification or artificial substances. Third, feasibility of preand post-harvest handling of RFA from the field to the consumer is questioned by stakeholders of the apple industry, especially apple growers and grower cooperatives. The expressed agronomic and technical concerns focused on the RFA yield, production cost, storability and quality maintenance. Fourth, RFA aspect can lead to disregarded taste expectations. The slightly acidic and bitter taste of the fruit might not be appreciated by some consumers. Then again, this may be a driver for RFA, especially for the health-conscious consumer segment. These consumers have a good nutritional knowledge and may associate the bitter and acidic with a higher content of phenolic compounds, and therefore, a higher nutritional value.

\section{Managerial Implications}

The apple industry is becoming increasingly competitive and faces several challenges. Introducing new apple varieties with a consumer-oriented approach leads to market sustainability and consumer satisfaction. RFA has gained attention by experts in the industry for product innovation. Results of the present study support the potential of RFA for the whole value chain sustainability. However, the following managerial implications for RFA market introduction and sustainability should be considered.

First, apple industry companies may develop a RFA management strategy aiming for a market positioning focused on the nutritional content and health benefits of RFA. Consumers and apple industry experts trust the RFA nutritional properties can be a strategic competitive advantage, especially to target health-conscious consumers. Past research has shown that the content of certain phytonutrients differs between traditional varieties, but also between $R F A$ varieties $[36,75,81]$. Therefore, claims about the nutritional value of the fruit should be based on the single RFA variety's nutritional composition. Second, RFA market introduction and sustainability should be based on adequate information of the origin and nutritional value of RFA. Results support that this will increase consumers' inclination towards RFA, and reduce consumers' food neophobia [64-66]. The initial challenge for the food industry when introducing new food products to the market is to make the consumer familiar with the product. Communicating origin, nutritional content, and taste of RFA through marketing campaigns, social media platforms, and in-store product information may help the consumer familiarize with the product and increase demand of the new fruit. Third, RFA companies may consider marketing RFA as an ingredient for the fruit processing industry. The color of the fruit pulp and the nutritional composition of RFA can create value for processed fruit products such as juices, fresh-cut fruit, fruit puree smoothies, etc. Fourth, RFA market introduction is evolving. There is increasing knowledge on consumers' initial perceptions and appreciation of RFA, as provided by the present research findings. RFA management should further analyze consumers' repurchase intention, and monitor sales and consumer feedback over time. This would support the definition of longer-term planning necessary for the effective coordination with other chain actors upstream and downstream of the chain. Finally, apple industry stakeholders should share knowledge and skills on pre- and post-harvest management 
of RFA. Marketed RFA quality relies on the application and respect of pre- and post-harvest handling rules of all actors intervening along the chain. There is need to increase the RFA chain coordination to achieve a successful and sustainable management. For example, RFA market introduction may consider to manage the new apple as a club variety with registered brand, trademark and planting rights. This would require the cooperation between RFA chain actors. Quality and production standards should be defined, set, respected, and communicated, expecting the cooperation of all chain actors. In a club variety system, RFA quantity would be regulated according to the market demand. Moreover, it would allow to fully value the RFA unique features, eventually leading to a premium price. The higher economic returns can be distributed among the chain actors, creating long-term sustainability of the apple chain actors and higher economic returns especially at the farming level, as for other club varieties [26-28,30,31,34,109].

\section{Conclusions}

Innovation is an important concept in the agricultural sector to achieve long-term sustainability from an economic, environmental, and social perspective [8]. Consumers' perception of food evolves in modern society, and strongly influences their food choices [96,97]. Understanding the potential of food product innovation from a consumer and industry perspective is crucial. This research is focused on analyzing the market potential of RFA as a novel food product in the fresh fruit market. By including consumer responses and expert and stakeholder opinions, the present study contributes to bridge the gap of past research and provide information on the value of RFA along the whole supply chain.

The present study shows that consumers know little about RFA. However, the new fruit awakens curiosity and interest and shows high rates of appreciation, willingness to try, and purchase intention. Consumers are particularly interested in the nutritional value of the fruit and its health benefits. However, consumers show some skepticism and inconclusiveness regarding origin, nutritional value and overall liking of the novel fruit. Many consumers associate RFA with genetic modification. Experts of the fruit industry believe that RFA are an interesting product innovation which contribute to a market advantage and consumers' sustainable food choice.

Limitations of this study should be considered. First, consumers were only shown pictures of RFA without seeing or tasting a real fruit. Furthermore, consumers belong to Western countries. Future research may expand the analysis to include other countries, especially Asian consumers. Moreover, it may be complemented with RFA tasting. Second, in-store experiments or experimental action could provide valuable information on consumers' fruit preference and willingness to pay for RFA. Further studies could investigate consumers' repurchase behavior, and long-term appreciation of the new fruit by analyzing sales data. Third, the survey was submitted to a convenience sample. This may limit the representativeness and generalizability of the findings. Yet, the sample provides a cross-country perspective and a comparative viewpoint that enrich the findings achieved. Future studies may extend the number of consumers interviewed and the multi-country approach. Fourth, further studies may assess the potential of RFA as an ingredient, by exploring consumers' perception of RFA-based processed fruit products (juice, fresh-cut, smoothie, etc.). Finally, future studies may also investigate management factors to optimize RFA production and post-harvest handling. A comparison of RFA production cost and conventional apple production cost might be useful to better assess the economic management sustainability of RFA for the industry. To conclude, this article can provide valuable information for fruit industry experts and stakeholders interested in investing in innovation and product development.

Author Contributions: Conceptualization: A.S. and M.Z.; methodology: A.S.; software: A.S. and M.Z.; validation: A.S., M.Z. and J.Y.; formal analysis: A.S.; investigation: M.Z.; data curation: M.Z.; writing-original draft preparation: A.S. and M.Z.; writing-review and editing: A.S., M.Z. and J.Y.; visualization: M.Z.; supervision: A.S. All authors have read and agreed to the published version of the manuscript.

Funding: This research received no external funding. 
Acknowledgments: The authors would like to thank Denise M. Conroy for her kind support during the research activities.

Conflicts of Interest: The authors declare no conflict of interest.

\section{Appendix A}

Table A1. Hypothesis Testing across Countries: Italy vs. New Zealand.

\begin{tabular}{|c|c|c|c|c|c|c|c|}
\hline \multirow{2}{*}{ Hypothesis } & \multirow{2}{*}{ Country } & \multirow{2}{*}{ Variable } & \multirow{2}{*}{ Mean } & \multirow{2}{*}{ St. Dev. } & \multicolumn{2}{|c|}{$T$-Test } & \multirow{2}{*}{ Supported } \\
\hline & & & & & $t$-value & $p$-value & \\
\hline \multicolumn{8}{|c|}{ Socio-Economic Characteristics } \\
\hline \multirow{5}{*}{ HP1_Gender } & \multirow{3}{*}{ IT } & & $\begin{array}{l}\text { RFA level of } \\
\text { appreciation } \\
\text { (mean) }\end{array}$ & & & & \\
\hline & & Male & 3.6 & 0.86 & -0.02 & 0.985 & No \\
\hline & & Female & 3.6 & 0.87 & & & \\
\hline & \multirow[t]{2}{*}{ NZ } & Male & 3.8 & 0.86 & -2.34 & $0.020 * *$ & Yes \\
\hline & & Female & 4.1 & 0.79 & & & \\
\hline \multirow{4}{*}{ HP2_Age (a) } & \multirow{2}{*}{ IT } & $<38$ & 3.8 & 0.86 & -3.72 & $0.000^{* * * *}$ & Yes \\
\hline & & $=>38$ & 3.4 & 0.81 & & & \\
\hline & \multirow[t]{2}{*}{ NZ } & $<38$ & 4.1 & 0.83 & -1.01 & 0.315 & No \\
\hline & & $=>40$ & 4.0 & 0.78 & & & \\
\hline \multirow{4}{*}{ HP3_Education } & \multirow[t]{2}{*}{ IT } & Non-academic & 3.6 & 0.91 & 0.89 & 0.369 & No \\
\hline & & Academic & 3.7 & 0.80 & & & \\
\hline & \multirow[t]{2}{*}{$\mathrm{NZ}$} & Non-academic & 4.1 & 0.83 & -0.95 & 0.344 & No \\
\hline & & Academic & 4.0 & 0.82 & & & \\
\hline \multirow[t]{4}{*}{ HP5_Children } & \multirow[t]{2}{*}{ IT } & No children & 3.6 & 0.87 & -1.25 & 0.212 & No \\
\hline & & Children & 3.5 & 0.85 & & & \\
\hline & \multirow[t]{2}{*}{ NZ } & No children & 4.0 & 0.81 & -0.58 & 0.558 & No \\
\hline & & Children & 4.0 & 0.82 & & & \\
\hline \multicolumn{8}{|c|}{ Consumers' Innovation- and Health-Orientation } \\
\hline \multirow{5}{*}{$\begin{array}{c}\text { HP9_Food } \\
\text { neophobia (FN) } \\
\text { (c) }\end{array}$} & \multicolumn{4}{|c|}{$\begin{array}{l}\text { RFA level of } \\
\text { appreciation } \\
\text { (mean) }\end{array}$} & & & \\
\hline & IT & Low FN & 3.9 & 0.77 & 3.81 & $0.000 * * *$ & Yes \\
\hline & \multirow{3}{*}{ NZ } & High FN & 3.5 & 0.87 & & & \\
\hline & & Low FN & 4.2 & 0.73 & 3.03 & $0.003^{* * * *}$ & Yes \\
\hline & & High FN & 3.9 & 0.84 & & & \\
\hline \multicolumn{8}{|c|}{ Consumers' RFA perception } \\
\hline \multirow{6}{*}{$\begin{array}{l}\text { HP10_RFA Belief } \\
\text { origin (d) }\end{array}$} & & & $\begin{array}{l}\text { RFA level of } \\
\text { appreciation } \\
\text { (mean) }\end{array}$ & & & & \\
\hline & IT & Natural origin & 3.7 & 0.83 & -2.12 & $0.035 * *$ & Yes \\
\hline & & Not natural origin & 3.5 & 0.90 & & & \\
\hline & NZ & Natural origin & 4.2 & 0.69 & -4.44 & $0.000^{* * *}$ & Yes \\
\hline & & Not natural origin & 3.8 & 0.88 & & & \\
\hline & & & WTT RFA & & & & \\
\hline $\begin{array}{l}\text { HP11_Belief in } \\
\text { RFA nutritional } \\
\text { value }\end{array}$ & IT & $\begin{array}{l}\text { Low belief in RFA } \\
\text { nutritional value }\end{array}$ & 4.2 & 0.80 & 3.8 & $0.000^{* * * *}$ & Yes \\
\hline & & $\begin{array}{l}\text { High belief in RFA } \\
\text { nutritional value }\end{array}$ & 4.5 & 0.68 & & & \\
\hline & NZ & $\begin{array}{l}\text { Low belief in RFA } \\
\text { nutritional value }\end{array}$ & 4.1 & 0.90 & 6.99 & $0.000^{* * *}$ & Yes \\
\hline & & $\begin{array}{l}\text { High belief in RFA } \\
\text { nutritional value }\end{array}$ & 4.6 & 0.61 & & & \\
\hline & & & $\begin{array}{l}\text { WTB RFA } \\
\text { (mean) }\end{array}$ & & & & \\
\hline
\end{tabular}


Table A1. Cont.

\begin{tabular}{|c|c|c|c|c|c|c|c|}
\hline \multirow{2}{*}{ Hypothesis } & \multirow{2}{*}{ Country } & \multirow{2}{*}{ Variable } & \multirow{2}{*}{ Mean } & \multirow{2}{*}{ St. Dev. } & \multicolumn{2}{|c|}{$T$-Test } & \multirow{2}{*}{ Supported } \\
\hline & & & & & $t$-Value & $p$-Value & \\
\hline \multirow[t]{4}{*}{$\begin{array}{c}\text { HP12_RFA } \\
\text { Nutritional value } \\
\text { interest }\end{array}$} & IT & $\begin{array}{l}\text { Low interest in RFA } \\
\text { nutritional value }\end{array}$ & 3.4 & 0.94 & 6.58 & $0.000^{* * *}$ & Yes \\
\hline & & $\begin{array}{l}\text { High interest in RFA } \\
\text { nutritional value }\end{array}$ & 4.0 & 0.58 & & & \\
\hline & NZ & $\begin{array}{l}\text { Low interest in RFA } \\
\text { nutritional value }\end{array}$ & 3.6 & 0.78 & 7.57 & $0.000^{* * *}$ & Yes \\
\hline & & $\begin{array}{l}\text { High interest in RFA } \\
\text { nutritional value }\end{array}$ & 4.2 & 0.45 & & & \\
\hline \multirow{5}{*}{$\begin{array}{l}\text { HP13_RFAWTT_WTB } \\
\text { (e) }\end{array}$} & IT & NWTT_NWTB RFA & 45.7 & & 21.41 & $0.000^{* * *}$ & Yes \\
\hline & & NWTT_WTB RFA & 54.3 & & & & \\
\hline & NZ & NWTT_NWTB RFA & 29.0 & & 37.22 & $0.000^{* * *}$ & Yes \\
\hline & & NWTT_WTB RFA & 71.1 & & & & \\
\hline & & & $\begin{array}{l}\text { WTP RFA } \\
\text { higher price }\end{array}$ & & & & \\
\hline \multirow[t]{4}{*}{$\begin{array}{c}\text { HP14_RFA } \\
\text { Nutritional value } \\
\text { interest }\end{array}$} & IT & $\begin{array}{l}\text { Low interest in RFA } \\
\text { nutritional value }\end{array}$ & 1.5 & 0.75 & 1.91 & $0.058^{*}$ & Yes \\
\hline & & $\begin{array}{l}\text { High interest in RFA } \\
\text { nutritional value }\end{array}$ & 1.7 & 0.81 & & & \\
\hline & NZ & $\begin{array}{l}\text { Low interest in RFA } \\
\text { nutritional value }\end{array}$ & 1.4 & 0.69 & 1.69 & $0.091 *$ & Yes \\
\hline & & $\begin{array}{l}\text { High interest in RFA } \\
\text { nutritional value }\end{array}$ & 1.6 & 0.60 & & & \\
\hline
\end{tabular}

Note: ${ }^{*}{ }^{* *} ; * * *$ Significant at $\mathrm{p}<0.10 ; \mathrm{p}<0.05 ; \mathrm{p}<0.01$; Mean values represent as specified in the table: "RFA level of appreciation" (How do you like RFA?), "Willingness to try RFA" (RFA WTT), “Willingness to buy RFA (RFA WTB)" and "Willingness to pay a higher price for RFA" on a 5-point Likert scale. The term "Low" groups responses as 1 = very low, 2 =low, and $3=$ neutral; and the term "High" groups responses as $4=$ high, and $5=$ very high on a 5-point Likert scale. (a) The sample average age is 38. (c) FNS score 23 was used as cut-off point comparing low food neophobia versus medium and high food neophobia. (d) Perceived origin of RFA: Possible answers were Natural versus Other that included genetically modified, artificial, other. (e) Values in percentage represent consumers not WTT (NWTT) and not WTB (NWTB) RFA after receiving information on the characteristics of RFA, and consumers not WTT but WTB RFA after receiving information on the characteristics of RFA. HP13 was tested with Pearson chi ${ }^{2}$ with $\mathrm{df}=1$.

\section{References}

1. Reid, M.; Buisson, D. Factors influencing adoption of new apple and pear varieties in Europe and the UK. Int. J. Retail. Distrib. Manag. 2001, 29, 315-327. [CrossRef]

2. Santeramo, F.; Carlucci, D.; De Devitiis, B.; Seccia, A.; Stasi, A.; Viscecchia, R.; Nardone, G. Emerging trends in European food, diets and food industry. Food Res. Int. 2018, 104, 39-47. [CrossRef] [PubMed]

3. World Health Organization. Healthy Diet. Available online: https:/www.who.int/news-room/fact-sheets/ detail/healthy-diet/ (accessed on 12 May 2020).

4. Harker, F.R.; Jaeger, S.R.; Gamble, J.; Richardson-Harman, N. Consumer acceptance of New Horticultural Crops. Compact. Fruit Tree 2005, 38, 26-30.

5. Hoek, A.; Pearson, D.; James, S.; Lawrence, M.; Friel, S. Healthy and environmentally sustainable food choices: Consumer responses to point-of-purchase actions. Food Qual. Prefer. 2017, 58, 94-106. [CrossRef]

6. Hennen, W.; Benninga, J. Application of Trend Impact Analysis for predicting future fruit consumption. J. Hortic. Sci. Biotechnol. 2009, 84, 18-21. [CrossRef]

7. Zimmermann, K.; Van Der Lans, I. The paradigm of consumer-driven and responsive supply chains: An integrated project approach. J. Hortic. Sci. Biotechnol. 2009, 84, 7-12. [CrossRef]

8. Sadovska, V.; Axelson, L.E.; Mark-Herbert, C. Reviewing Value Creation in Agriculture-A Conceptual Analysis and a New Framework. Sustainability 2020, 12, 5021. [CrossRef]

9. Kraszewska, M.; Zajac, J.; Van Der Lans, I.; Jasiulewicz, A.; Berg, I.V.D.; Bolek, A. Role of product characteristics for the adoption of fruit and fruit product innovations. J. Hortic. Sci. Biotechnol. 2009, 84, 28-33. [CrossRef]

10. Verhees, F.J.; Lans, T.; Verstegen, J.A. The influence of market and entrepreneurial orientation on strategic marketing choices: The cases of Dutch farmers and horticultural growers. J. Chain Netw. Sci. 2012, 12, 167-179. [CrossRef] 
11. Bonany, J.; Brugger, C.; Buehler, A.; Carbó, J.; Codarin, S.; Donati, F.; Echeverria, G.; Egger, S.; Guerra, W.; Hilaire, C.; et al. Preference mapping of apple varieties in Europe. Food Qual. Prefer. 2014, 32, 317-329. [CrossRef]

12. Briz, T.; Sijtsema, S.J.; Jasiulewicz, A.; Kyriakidi, A.; Guàrdia, M.D.; van den Berg, I.; Lans, I.A. van der Barriers to Fruit Consumption: Driving Forces behind Consumer Behaviour. Scripta Horticulturae 2008, 8, 7-18.

13. Statista. Statista • Global Top Apple Exporters Worldwide 2019. Available online: https://www.statista.com/ statistics/756433/global-top-apple-exporter-worldwide/ (accessed on 29 April 2020).

14. Maas, F.M.; Heijerman-Peppelman, G.; Groot, M.J.; Schoorl, F.W.; van der Linden, K. Introducing new apple cultivars through a coordinated approach from consumer till breeder. Acta Hortic. 2012, 940, 433-438. [CrossRef]

15. Lievens, E.; Bonjean, I.; Dabrowski, A.; Minarelli, F.; Gorlach, K.; Raggi, M.; Nowak, P.; Viaggi, D.; Mathijs, E. Cooperatives adapting to market conditions: Insights from a comparative study of apple and pear farming in Poland, Italy and Belgium. In Proceedings of the 13th European IFSA Symposium, Chania, Greece, 1-5 July 2018; Theme 5-Sustainable agrifood systems, value chains and power structures.

16. Harker, F.; Gunson, F.; Jaeger, S.R. The case for fruit quality: An interpretive review of consumer attitudes, and preferences for apples. Postharvest Boil. Technol. 2003, 28, 333-347. [CrossRef]

17. D'Aveni, R.A.; Günther, R. Hypercompetition. Managing the Dynamics of Strategic Maneuvering. In Das Summa Summarum des Management; Springer Science and Business Media LLC: Berlin/Heidelberg, Germany, 2007; pp. 83-93.

18. European Commission. Dg Agri Dashboard: Apples. Available online: https://ec.europa.eu/info/sites/info/ files/food-farming-fisheries/farming/documents/apple-dashboard_en.pdf (accessed on 22 July 2020).

19. Fresh Plaza. Overview Global Apple Market. Available online: https://www.freshplaza.com/article/9156688/ overview-global-apple-market/ (accessed on 22 July 2020).

20. Landes, M.; Krissoff, B. Prospects for India's emerging apple market. Prospects 2006, 1, 1-38.

21. Chinese Apples and the Emerging World Food Trade Order: Food Safety, International Trade, and Regulatory Collaboration between China and the European Union. Chin. J. Comp. Law 2017, 5, 253-307. [CrossRef]

22. Lee, K.; Gallardo, R.K.; Giacinti, M. The Indian Demand for Imported Fresh Apples: Effects of Tariff Reductions. J. Agric. Appl. Econ. 2019, 52, 30-46. [CrossRef]

23. Luckstead, J.; Devadoss, S.; Mittelhammer, R.C. Apple Export Competition between the United States and China in the Association of Southeast Asian Nations. J. Agric. Appl. Econ. 2014, 46, 635-647. [CrossRef]

24. Arora, T. INDIA: Potential of Apple Imports. In Proceedings of the Interpoma 2018, Bolzano, Italy, 15-17 November 2018.

25. Skinner, R.C.; Gigliotti, J.C.; Ku, K.-M.; Tou, J.C. A comprehensive analysis of the composition, health benefits, and safety of apple pomace. Nutr. Rev. 2018, 76, 893-909. [CrossRef]

26. Luby, J.J.; Bedford, D.S. Cultivars as Consumer Brands: Trends in Protecting and Commercializing Apple Cultivars via Intellectual Property Rights. Crop. Sci. 2015, 55, 2504-2510. [CrossRef]

27. Legun, K. Club apples: A biology of markets built on the social life of variety. Econ. Soc. 2015, 44, $293-315$. [CrossRef]

28. Меженський, В.М.; Якубенко, Н.Б. New trends in protection of plant breeder's rights on the example of apple varieties: Cultivars as trademarks, clubs and brands. Plant Var. Stud. Prot. 2020, 16, 5-16. [CrossRef]

29. Researchgate. Update on New Apple Varieties, Managed Varieties and Clubs. Available online: https://www.researchgate.net/publication/329327635_Update_on_new_apple_varieties_managed_ varieties_and_Clubs (accessed on 22 July 2020).

30. Van der Weeken, M. Prices of Club Varieties Satisfying in Difficult Top Fruit Season. Available online: https://www.freshplaza.com/article/9111978/prices-of-club-varieties-satisfying-in-difficult-top-fruitseason/ (accessed on 24 July 2020).

31. Winton, J. Opinion: Pros and Cons of Club Varieties-FreshFruitPortal.com. Available online: https: //www.freshfruitportal.com/news/2017/08/14/opinion-pros-cons-club-varieties/ (accessed on 24 July 2020).

32. Fresh Plaza. Lowette Filip "We Believe in Club Varieties". Available online: https://www.freshplaza.com/ article/9082854/we-believe-in-club-varieties/ (accessed on 24 July 2020).

33. WisContext. The Rise of Apple Clubs and Trademark Varieties of Fruit. Available online: https://www. wiscontext.org/rise-apple-clubs-and-trademark-varieties-fruit (accessed on 24 July 2020). 
34. Canavari, M. Marketing Research on Fruit Branding. In Case Studies in the Traditional Food Sector; Elsevier BV: Amsterdam, The Netherlands, 2018; pp. 239-254.

35. Guerra, W.; Bradlwarter, M. Red fleshed apples Apfelsorten mit rotem Fruchtfleisch Mele a polpa rossa. In Proceedings of the Interpoma 2012, Bolzano, Italy, 15-17 November 2012; pp. 1-18.

36. Espley, R.V.; Bovy, A.; Bava, C.; Jaeger, S.R.; Tomes, S.; Norling, C.; Crawford, J.; Rowan, D.D.; McGhie, T.; Brendolise, C.; et al. Analysis of genetically modified red-fleshed apples reveals effects on growth and consumer attributes. Plant Biotechnol. J. 2012, 11, 408-419. [CrossRef]

37. Knowels, M. Green Light for Red-Fleshed Apples. Available online: http://www.fruitnet.com/eurofruit/ article/180014/green-light-for-red-fleshed-apples (accessed on 24 July 2020).

38. Fresh Plaza. Red-Flesh Apples Get First Commercial Trials. Available online: https://www.freshplaza.com/ article/2189091/red-flesh-apples-get-first-commercial-trials/ (accessed on 22 July 2020).

39. Fresh Plaza. Red Moon Company Shows off New Red Fleshed Apple Brand. Available online: https://www. freshplaza.com/article/2188473/red-moon-company-shows-off-new-red-fleshed-apple-brand/ (accessed on 22 July 2020).

40. Fresh Plaza. Three New Red-Flesh Apple Varieties Presented in Madrid. Available online: https:// www.freshplaza.com/article/2164615/three-new-red-flesh-apple-varieties-presented-in-madrid/ (accessed on 22 July 2020).

41. Rusnak, P. Red-Fleshed Apple Commercialization Program Announced-Growing Produce. Available online: https://www.growingproduce.com/fruits/red-fleshed-apple-commercialization-program-announced/ (accessed on 22 July 2020).

42. Fresh Plaza. Red-Fleshed Apples Becoming a Global Trend. Available online: https://www.freshplaza.com/ article/9101329/red-fleshed-apples-becoming-a-global-trend/ (accessed on 22 July 2020).

43. Guerra, W. Today s New Varieties Global Trends in Variety Innovation. In Proceedings of the Interpoma 2018, Bolzano, Italy, 15-17 November 2018.

44. Bonany, J.; Buehler, A.; Carbó, J.; Codarin, S.; Donati, F.; Echeverria, G.; Egger, S.; Guerra, W.; Hilaire, C.; Holler, I.; et al. Consumer eating quality acceptance of new apple varieties in different European countries. Food Qual. Prefer. 2013, 30, 250-259. [CrossRef]

45. Furst, T.; Connors, M.; Bisogni, C.A.; Sobal, J.; Falk, L.W. Food Choice: A Conceptual Model of the Process. Appetite 1996, 26, 247-266. [CrossRef] [PubMed]

46. Costell, E.; Tarrega, A.; Bayarri, S. Food Acceptance: The Role of Consumer Perception and Attitudes. Chemosens. Percept. 2009, 3, 42-50. [CrossRef]

47. Grunert, K.G. (Ed.) Consumer Trends and New Product Opportunities in the Food Sector; Wageningen Academic Publishers: Wageningen, The Netherlands, 2017.

48. Samoggia, A.; Nicolodi, S. Consumer's Perception of Fruit Innovation. J. Int. Food Agribus. Mark. 2017, 29, 92-108. [CrossRef]

49. Bertazzoli, A.; Buccioli, N.; Nocella, G. Consumers' Perception and Evaluation of Fresh Cut Buying Attributes: A Survey on the Italian Market. J. Food Prod. Mark. 2005, 11, 35-55. [CrossRef]

50. Baselice, A.; Colantuoni, F.; Lass, D.A.; Nardone, G.; Stasi, A. Trends in EU consumers' attitude towards fresh-cut fruit and vegetables. Food Qual. Prefer. 2017, 59, 87-96. [CrossRef]

51. Enneking, U.; Neumann, C.; Henneberg, S. How important intrinsic and extrinsic product attributes affect purchase decision. Food Qual. Prefer. 2007, 18, 133-138. [CrossRef]

52. Rooney, C.; McKinley, M.C.; Appleton, K.M.; Young, I.S.; McGrath, A.J.; Draffin, C.R.; Hamill, L.L.; Woodside, J. How much is '5-a-day'? A qualitative investigation into consumer understanding of fruit and vegetable intake guidelines. J. Hum. Nutr. Diet. 2016, 30, 105-113. [CrossRef]

53. Siró, I.; Kápolna, E.; Kápolna, B.; Lugasi, A. Functional food. Product development, marketing and consumer acceptance-A review. Appetite 2008, 51, 456-467. [CrossRef] [PubMed]

54. Ares, G.; Giménez, A.; Gámbaro, A. Influence of nutritional knowledge on perceived healthiness and willingness to try functional foods. Appetite 2008, 51, 663-668. [CrossRef] [PubMed]

55. Yoo, Y.J.; Saliba, A.; Macdonald, J.B.; Prenzler, P.D.; Ryan, D. A cross-cultural study of wine consumers with respect to health benefits of wine. Food Qual. Prefer. 2013, 28, 531-538. [CrossRef]

56. Samoggia, A. Wine and health: Faraway concepts? Br. Food J. 2016, 118, 946-960. [CrossRef] 
57. Barauskaite, D.; Gineikiene, J.; Auruskeviciene, V.; Fennis, B.M.; Yamaguchi, M.; Kondo, N. Eating healthy to impress: How conspicuous consumption, perceived self-control motivation, and descriptive normative influence determine functional food choices. Appetite 2018, 131, 59-67. [CrossRef]

58. Dolgopolova, I.; Teuber, R.; Bruschi, V. Consumers' perceptions of functional foods: Trust and food-neophobia in a cross-cultural context. Int. J. Consum. Stud. 2015, 39, 708-715. [CrossRef]

59. Hall, S. Increasing Fruit Consumption to Improve Health. In Proceedings of the ISAFRUIT Forum, Brussels, Belgium, 28 October 2008; ISBN 9789066056510.

60. Barrena, R.; Sánchez, M. Neophobia, personal consumer values and novel food acceptance. Food Qual. Prefer. 2013, 27, 72-84. [CrossRef]

61. Martins, Y.; Pelchat, M.L.; Pliner, P. “Try it; it's good and it's good for you”: Effects of Taste and Nutrition Information on Willingness to Try Novel Foods. Appetite 1997, 28, 89-102. [CrossRef]

62. Pliner, P.; Hobden, K. Development of a scale to measure the trait of food neophobia in humans. Appetite 1992, 19, 105-120. [CrossRef]

63. Tuorila, H.; Hartmann, C. Consumer responses to novel and unfamiliar foods. Curr. Opin. Food Sci. 2020, 33, 1-8. [CrossRef]

64. Kraus, A. Factors influencing the decisions to buy and consume functional food. Br. Food J. 2015, 117, 1622-1636. [CrossRef]

65. Jaeger, S.R.; Rasmussen, M.A.; Prescott, J. Relationships between food neophobia and food intake and preferences: Findings from a sample of New Zealand adults. Appetite 2017, 116, 410-422. [CrossRef] [PubMed]

66. Jaeger, S.R.; Harker, F. Consumer evaluation of novel kiwifruit: Willingness-to-pay. J. Sci. Food Agric. 2005, 85, 2519-2526. [CrossRef]

67. Schifferstein, H.N.; Wehrle, T.; Carbon, C.-C. Consumer expectations for vegetables with typical and atypical colors: The case of carrots. Food Qual. Prefer. 2019, 72, 98-108. [CrossRef]

68. Kallas, Z.; Vitale, M.; Gil, J.M.G. Health Innovation in Patty Products. The Role of Food Neophobia in Consumers' Non-Hypothetical Willingness to Pay, Purchase Intention and Hedonic Evaluation. Nutrition 2019, 11, 444. [CrossRef]

69. Goulart, G.D.S.; Viana, M.M.; Lucchese-Cheung, T. Consumer perception towards familiar and innovative foods: The case of a Brazilian product. Br. Food J. 2020. [CrossRef]

70. Biondi, B.; Camanzi, L. Nutrition, hedonic or environmental? The effect of front-of-pack messages on consumers' perception and purchase intention of a novel food product with multiple attributes. Food Res. Int. 2020, 130, 108962. [CrossRef]

71. Hartmann, C.; Ruby, M.; Schmidt, P.; Siegrist, M. Brave, health-conscious, and environmentally friendly: Positive impressions of insect food product consumers. Food Qual. Prefer. 2018, 68, 64-71. [CrossRef]

72. Harker, R. Consumer Response to Apples. In Proceedings of the Washington Tree Fruit Postharvest Conference 2001, Wenatchee, WA, USA, 13-14 March 2001; pp. 1-7.

73. Bars-Cortina, D.; Macià, A.; Iglesias, I.; Romero, M.P.; Motilva, M.-J. Phytochemical Profiles of New Red-Fleshed Apple Varieties Compared with Traditional and New White-Fleshed Varieties. J. Agric. Food Chem. 2017, 65, 1684-1696. [CrossRef]

74. Ceschi, S.; Canavari, M.; Castellini, A. Consumer's Preference and Willingness to Pay for Apple Attributes: A Choice Experiment in Large Retail Outlets in Bologna (Italy). J. Int. Food Agribus. Mark. 2017, 30, $305-322$. [CrossRef]

75. Silvestri, C.; Cirilli, M.; Zecchini, M.; Muleo, R.; Ruggieri, A. Consumer Acceptance of the New Red-Fleshed Apple Variety. J. Food Prod. Mark. 2016, 24, 1-21. [CrossRef]

76. Volz, R.; Oraguzie, N.; Whitworth, C.; How, N.; Chagné, D.; Carlisle, C.; Gardiner, S. Red flesh breeding in apple-Progress and challenges. Acta Hortic. 2009, 814, 337-342. [CrossRef]

77. Fresh Plaza. A Surprise Inside: New Variety of Red-Fleshed Apples. Available online: https://www.freshplaza. com/article/9158587/a-surprise-inside-new-variety-of-red-fleshed-apples/ (accessed on 22 July 2020).

78. Faramarzi, S.; Pacifico, S.; Yadollahi, A.; Lettieri, A.; Nocera, P.; Piccolella, S. Red-fleshed Apples: Old Autochthonous Fruits as a Novel Source of Anthocyanin Antioxidants. Plant Foods Hum. Nutr. 2015, 70, 324-330. [CrossRef] [PubMed]

79. Sato, H.; Otagaki, S.; Ono, Y.; Shiratake, K.; Matsumoto, S. Upregulation ofMdMYB110ais responsible for ABA-mediated colouration of type 2 red-fleshed apples. J. Hortic. Sci. Biotechnol. 2018, 94, 33-40. [CrossRef] 
80. Rupasinghe, H.P.; Huber, G.M.; Embree, C.; Forsline, P.L. Red-fleshed apple as a source for functional beverages. Can. J. Plant Sci. 2010, 90, 95-100. [CrossRef]

81. Wang, X.; Li, C.; Liang, D.; Zou, Y.; Li, P.-M.; Ma, F. Phenolic compounds and antioxidant activity in red-fleshed apples. J. Funct. Foods 2015, 18, 1086-1094. [CrossRef]

82. Cirilli, M.; Latini, G.; Cristofori, V.; Ceccantoni, B.; Luziatelli, F.; Zecchini, M.; Muleo, R.; Ruzzi, M. Polyphenol traits, antimicrobial property and consumer preference of 'Italian Red Passion' apple genotypes and cultivar 'Annurca'. Acta Hortic. 2015, 185-190. [CrossRef]

83. Sato, H.; Otagaki, S.; Saelai, P.; Kondo, S.; Shiratake, K.; Matsumoto, S. Varietal differences in phenolic compounds metabolism of type 2 red-fleshed apples. Sci. Hortic. 2017, 219, 1-9. [CrossRef]

84. Balazs, A.; Tóth, M.; Blazics, B.; Héthelyi, É.; Szarka, S.; Ficsor, E.; Ficzek, G.; Lemberkovics, E.; Blázovics, A. Investigation of dietary important components in selected red fleshed apples by GC-MS and LC-MS. Fitoterapia 2012, 83, 1356-1363. [CrossRef]

85. Fresh Plaza. Internal Browning Flesh Disorder: A Critical Issue for Novel Red-Fleshed Apples. Available online: https://www.freshplaza.com/article/9166085/internal-browning-flesh-disorder-a-critical-issue-fornovel-red-fleshed-apples/ (accessed on 22 July 2020).

86. Wellner, A.; Grimm, E.; Knoche, M. Effect of Orchard Management Factors on Flesh Color of Two Red-Fleshed Apple Clones. Horticulturae 2019, 5, 54. [CrossRef]

87. Bars-Cortina, D.; Macià, A.; Iglesias, I.; Garanto, X.; Badiella, L.; Motilva, M.-J. Seasonal Variability of the Phytochemical Composition of New Red-Fleshed Apple Varieties Compared with Traditional and New White-Fleshed Varieties. J. Agric. Food Chem. 2018, 66, 10011-10025. [CrossRef] [PubMed]

88. Honda, C.; Iwanami, H.; Naramoto, K.; Maejima, T.; Kanamaru, K.; Moriya-Tanaka, Y.; Hanada, T.; Wada, M. Thinning and Bagging Treatments and the Growing Region Influence Anthocyanin Accumulation in Red-fleshed Apple Fruit. Hortic. J. 2017, 86, 291-299. [CrossRef]

89. Jaeger, S.R.; Rossiter, K.; Wismer, W.; Harker, F. Consumer-driven product development in the kiwifruit industry. Food Qual. Prefer. 2003, 14, 187-198. [CrossRef]

90. Gregory, A.; Thomas, A. Consumer response to genetically modified foods: Market segment analysis and implications. J. Agric. Res. Econ. 2001, 26, 387-403.

91. Carrillo, E.; Varela, P.; Salvador, A.; Fiszman, S. Main Factors Underlying Consumers' Food Choice: A First Step for the Understanding of Attitudes Toward Healthy Eating. J. Sens. Stud. 2011, 26, 85-95. [CrossRef]

92. Reddivari, L.; Vanamala, J.; Chintharlapalli, S.; Safe, S.H.; Miller, J.C. Anthocyanin fraction from potato extracts is cytotoxic to prostate cancer cells through activation of caspase-dependent and caspase-independent pathways. Carcinogenesis 2007, 28, 2227-2235. [CrossRef] [PubMed]

93. Endrizzi, I.; Torri, L.; Corollaro, M.L.; Demattè, M.L.; Aprea, E.; Charles, M.; Biasioli, F.; Gasperi, F. A conjoint study on apple acceptability: Sensory characteristics and nutritional information. Food Qual. Prefer. 2015, 40,39-48. [CrossRef]

94. Sheu, S.-J.; Wei, I.-L.; Chen, C.-H.; Yu, S.; Tang, F.-I. Using snowball sampling method with nurses to understand medication administration errors. J. Clin. Nurs. 2009, 18, 559-569. [CrossRef]

95. Brooks, F.B.; Rubin, H.J.; Rubin, I.S. Qualitative Interviewing: The Art of Hearing Data. Mod. Lang. J. 1996, 80, 555. [CrossRef]

96. Van Trijp, H.C.; Van Kleef, E. Newness, value and new product performance. Trends Food Sci. Technol. 2008, 19, 562-573. [CrossRef]

97. Aarikka-Stenroos, L.; Lehtimaki, T. Commercializing a radical innovation: Probing the way to the market. Ind. Mark. Manag. 2014, 43, 1372-1384. [CrossRef]

98. King, E.S.; Johnson, T.E.; Bastian, S.E.; Osidacz, P.; Francis, I. Consumer liking of white wines: Segmentation using self-reported wine liking and wine knowledge. Int. J. Wine Bus. Res. 2012, 24, 33-46. [CrossRef]

99. Johnson, T.E.; Bastian, S.E. A preliminary study of the relationship between Australian wine consumers' wine expertise and their wine purchasing and consumption behaviour. Aust. J. Grape Wine Res. 2007, 13, 186-197. [CrossRef]

100. Ristic, R.; Johnson, T.E.; Meiselman, H.L.; Hoek, A.C.; Bastian, S.E.P. Towards development of a Wine Neophobia Scale (WNS): Measuring consumer wine neophobia using an adaptation of The Food Neophobia Scale (FNS). Food Qual. Prefer. 2016, 49, 161-167. [CrossRef]

101. McIntosh, M.J.; Morse, J.M. Situating and Constructing Diversity in Semi-Structured Interviews. Glob. Qual. Nurs. Res. 2015, 2, 2. [CrossRef] [PubMed] 
102. Forman, J.; Damschroder, L. Qualitative Content Analysis. Adv. Bioeth. 2007, 11, 39-62.

103. Kvale, S. (Ed.) InterViews: An Introduction to Qualitative Research Interviewing, 1st ed.; Sage Publications: Thousand Oaks, CA, USA, 1996; Volume 1.

104. Aikman, S.N.; Min, K.E.; Graham, D. Food attitudes, eating behavior, and the information underlying food attitudes. Appetite 2006, 47, 111-114. [CrossRef]

105. Kiefer, I.; Rathmanner, T.; Kunze, M. Eating and dieting differences in men and women. J. Men's Health Gend. 2005, 2, 194-201. [CrossRef]

106. Fernández-Ruiz, V.; Claret, A.; Chaya, C. Testing a Spanish-version of the Food Neophobia Scale. Food Qual. Prefer. 2013, 28, 222-225. [CrossRef]

107. Henriques, A.S.; King, S.C.; Meiselman, H.L. Consumer segmentation based on food neophobia and its application to product development. Food Qual. Prefer. 2009, 20, 83-91. [CrossRef]

108. Ruggeri, A.; Arvola, A.; Samoggia, A.; Hendrixson, V. Food behaviours of Italian consumers at risk of poverty. Br. Food J. 2015, 117, 11. [CrossRef]

109. Asioli, D.; Aschemann-Witzel, J.; Caputo, V.; Vecchio, R.; Annunziata, A.; Næs, T.; Varela, P. Making sense of the "clean label" trends: A review of consumer food choice behavior and discussion of industry implications. Food Res. Int. 2017, 99, 58-71. [CrossRef] [PubMed]

(C) 2020 by the authors. Licensee MDPI, Basel, Switzerland. This article is an open access article distributed under the terms and conditions of the Creative Commons Attribution (CC BY) license (http://creativecommons.org/licenses/by/4.0/). 